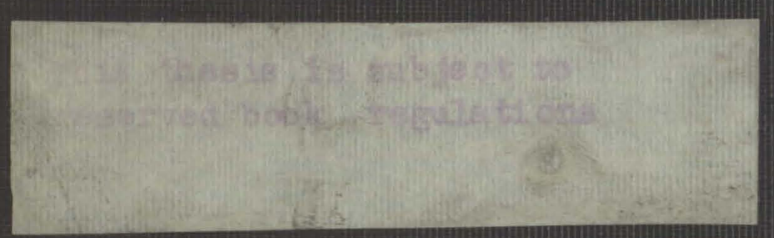



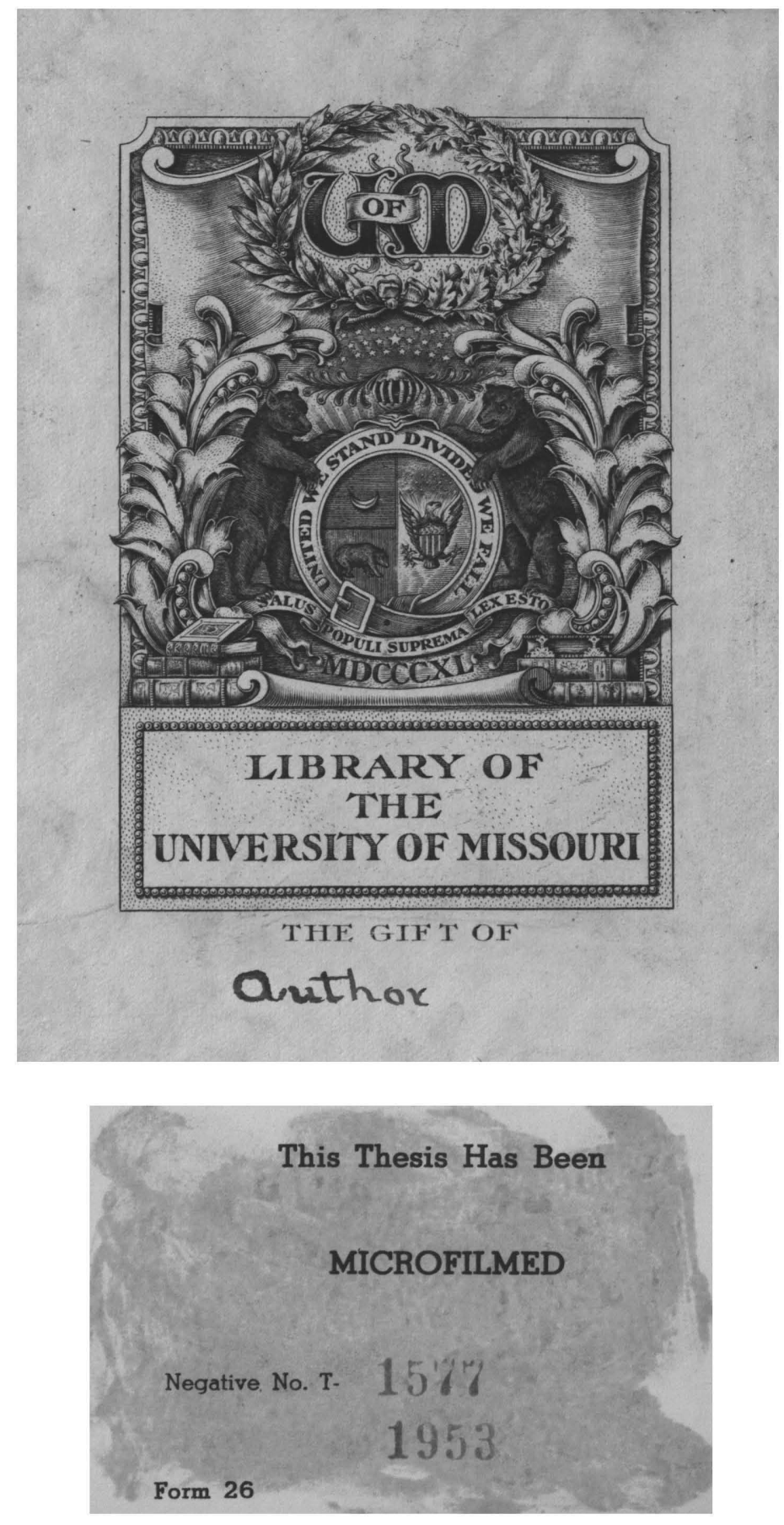




THE; HOMERIC HOUSE:

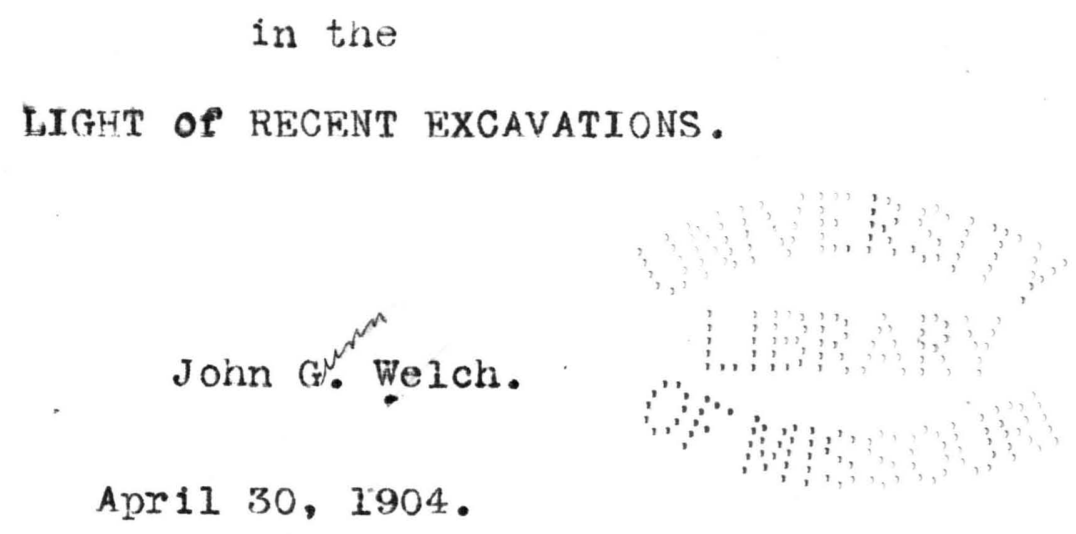

April 30, 1904.

Sresented as partial fulfilment of the requirement for the degree of master of Anta. 

$378.7 M 71$

XV44

The Homer 1c House.

The purpose of this paper is to give a detalied description of the Homeric house, according to the information to be had from the Homeric poens, and to compare it with other palaces of early antiquity, such as those of Tiryns, Mycenae, Knossos and Phaistos.

The house of a fairly rich man, or of a king, in Homeric t1mes, had, so far as we can learn from Homer, many appeliations. It was called most commonly, perhaps, "megara", which is used almost always to denote the wille house.(1). Another very common name 18 "domos", "lso used to denote the whole palace, and differing in no way proln "megara" (2). The word "oikos" is perhaps the most general name that we have. It seems to denote the whole establsisment, incluiding the house and the outside farms that belois to (t) (3). A word somewhat less general in its meaning is "doma". This seems to apply rather to that part of the house under a roof, and not, like "oikos", to the surrounding land (4). The piural of this word, "domata", is used in a broader sense than the singular, much more like "megara", above, and indeed, "domata" is nearlt as frequently used (5). All these terms differ very little in their meaning, and are in fact so nearly synonymous, that they do not herit further attention.

The house was entirely sarrounded by a high wall, which was probably rectangular in shape, and was divided into two parts, distinctiy marked, the "aule" and the house proper. The "aule" is an open, unroofed court, sorrounded by the same wall that surrounds the house, and lying directiy in front of the latter. The house is a two-story structure, inside of the surrounding wall, to which access is had from the "aule". This in turn is entered by means of a "prothyron", or door, in the wall opposite the front of the house.

1.0d.I. 269; II. 94; III. 256; IV. 392; VIII. 227; etc. 2.0d.I. 330; IV. 43; IV. 618; VIII. 22; etc. 3.0d.I. 258; II. 59; IV. 145; VII. 77; X. 474; etc, 4.0d.I. 227; IV. 46; VII. 85; X. 62; XIII. 4; etc. 5.Od.III. 388; IV. 174; V. 38I; VII. 46; VIII. 4I; etc. $930809)$ 

The "Aule".

We know that there was only one "aule" in the Homeric house, from the fact that it is mentioned only in the singular in all the different places where $1 \mathrm{t}$ is mentioned. This point, however, has been disputed. Perrot and Chipiez(6) have endeavored to prove that since the palace at Tiryns has apparently two "aula1", and one has been called the women's "aule" the Homer1c house also had two "aulal", one for the women, one for the men. This theory, however, is not based on fact, but on a desire to reconstruct the Homeric house on the ines of the palace at Tiryns, and we can easily disprove 1t froin the very fact that only one "aule" is mentioned.

The "aule" lay directly before the house, and one enterIng the "prothyron", or front gateway, was obliged to pass directiy through the "aule", to get into the house. This is shown from the foliowing passages. When Athene, in the guise of Mentes, came to visit the house of Odysseus, she found the suitors, seated in the "aule", playing garnes (7). Then, a little later, they all came directly into the house to the meal (8). Athene herself had been standing in the front "prothyron", and was brought by Telewachos into the house(9). But we gain perhaps the clearest conception of the relative position of house and "aule", from the ending of the fight between Odysseus and Iros. The fight took place in the house itself, and when Odysseus had conquered Iros, he dragged $\mathrm{h}$ im out of the house, through the portico before the door, thence through the "aule" to the opposite wall.(10). About the size of the "aule" we are not able to say very much. We learn that chariots were driven in here, and that the sultors threw the discus and javelin in the "aule" at the house of Odysseus, so it must have been quite large.

This will be taken up more in deta1l, when the various uses, to which the "aule" was put, are described.

In order to get a better idea of the "aule" as a whole, however, It w1ll be necessary to take it up in detail, and exainine the different parts, as well as the structures that are in the enclosure.

$$
\begin{aligned}
& \text { 6. H18toire de I'Art, Vol. VII. p.94. 7.0d.I. } 106, \mathrm{ff} \text {. } \\
& \text { 8.0d.I. 144. 9.0d.I. 126. 10.0d.XVIII. 101. }
\end{aligned}
$$



The Wall of the "Aule".

The. "aule" of the Homeric house was enclosed on three sides by the wall that surrounded the whole house, and on the other by the house itself, Odysseus mentions the wall, as he approached it in company with the swineherd, in his description of the effect that the whole house makes upon him (II). When he had conquered Iros in the fight. he dragged him through the "aule", and set him up against the wall at the front of the "aule" (12). Again, when Phoinix was shut up by his kinsmen to prevent his escaping from the house, he managed to get out of $\mathrm{nis}$ room and scale the wall of the "aule", thus making his escape (13). These passages show with sufficient clearness the fact of the existence of the wall around the "aule" and fouse; now let us exanine its construction and appearance.

We know little about the height of the wall, but since Phoinix managed to get over the wall of the palace of his father, without attracting any attention, in that'case, at least, It could not have been very high (13). The wall of th the "aule" of the establishment of the swineherd, Fumaios, has been described somewhat'carefully, and although this is only a hut, and hence can not be regarded as giveng convincing evidence with tegard to the wall of the house, yet it may throw some light upon that. Fumaios made the wall himself, building it carefully of stones, and placed around the top a coping of thorns. Then on the outside of all this he built a stockade of oak stakes, oriven into the ground close together (14). Now in all probability there was no stockade around the outside of the wall of $\mathrm{kings}$ palaces, yet it was sundoubtedly built of stone, and we know that there was a coping upon 1t, because odysseus expressly mentions 1t, when, in the gitse of a beggar, he first approaches the house, in company with Eumaios(11).

11.0d.XVII. 266. 12.0d.XVIII. 102. 13.11.1X. .476. 14. Od.XJV. 10-14. 



\section{The "Prothyron".}

The "prothyron" is the gate of the "aule", but the word 1tself is not confined to that meaning, but is also applied to that space in front of the door of the nouse, more commonly called the "prodomos". In the latter sense it will be treated under the head, "prodomos".

The "prothyron" is situated in all probability in the middle of the front wall of the "aule", as the naturel place for the front gate of the house. It is used, first of all, by persons arriving on foot. Through it Athene enters in the guise of Mentes, when she visited the house of Odysseus (15). She stopped in the "prothyron" and is brought in by

Telemachos, who, sitting in the "aule" among the suitors, sees her there and brings her into the house.

The "prothyron" was also the carriage-entrance of the house, and chariots and horses could pass through the entrance into the "aule". This was a common occurrence and is mentioned in several places, particularly in connection with the trip of Peisistratos and Telemachos, to the house of Menelaos. When they left the house of Diokles, in driving out of the "aule" it is said that they drove out of the "prothyron" and the "aithousa" (16). Likewise, when they left the house of Menelaos (17), and for a second time, the house of Diokles (18), we learn that they drove out of the "prothyron" and the "aithousa" in their chariot.

We see also that the gateway had some sort of threshold, from the fact that Athene stood on the threshold of the "aule", before she was seen by Telemachos (19). In the house of Alkinoos, a stream of water ran under this threshold toward the house (20). We have no passage which distinctly shows the material out of which the threshold was liade, but It must have been of some very durable mater1al, probably stone, and also very low to allow chariots to pass over 1 . Then, too, in the palace at Tiryns, we have stone thresholds, level with the ground, in the "prothyra".

We may get some 1dea of the external appearance of the "prothyron" from Odysseus' description of his house, as he

$$
\begin{array}{lll}
\text { 15. Od.I. 103. 16. Od.III. } 493 . & \text { 17. Od.XV. } 146 . \\
\text { 18. Od.XV. 191. } & \text { 19. Od.I. 104. } & \text { 20. Od. VII. } 130 .
\end{array}
$$



approaches it in the guise of a beggar (21). He says, "There is building upon bullding, the "aule' is furnished with a wall and a coping, and the double doors are well made." This last point alone has reference to our case, the mention of the doors. Apparentiy they were a prominent reature in the front of the house, to one who is approaching. These doors were double, rested on the threshold, nentioned above, and were probabiy of wood, though this is nowhere specifically mentioned. These doors are called, in general, "doors of the "aule'", and are mentioned in various places and connections. When the suitors plotted against Telemachos, they went out of the "aule" and sat down before the doors (22). When

odysseus made himself known to the servants, Furnaios, and Philoitios, he first took them outside of the doors of the "aule" (23). In one place they are called the doors of the "althousa", and immediately after, the doors of the "aule", showing that the terms are interchangeable. This occurs when Odysseus has overcone Iros, and, after dragging him out of the house, has placed him against the wall of the "aule", near the door of the "althousa" (24). Later, Telemachos speaks of Iros, as being near the doors of the "aule" (25). These doors, besides being double, were likewise furntshed with a lock, or bar, for closing and locking. At the time of the slaughter of the suitors, or slightly before, Odysseus gives Philoitios, the swineherd, the task of lockIng these doors to prevent the escape of the suitors (26). Th1s task he afterwards performs, tying the door with a rope, which he picks up under the "althousa", close to the gate (27).

As to the construction of this "prothyron", It may have been in the nature of a propylaeun, with a pottico opening into the "aule" as well as outside, and may have had columns to support the toof at sides and front. But we have no proof of this, ercept in so far as we can take the palace at Tiryns as proof. For this palace did have the propylaea, with the double portico, and the columns supporting the roof. At any rate the entrance was wide enough to allow chariots and horses to pass through, and on the threshold were, of

$$
\begin{aligned}
& \text { 21.0d.XVII. 266. 22.0d.XVI.344. 23.0d.XXI. } 191 . \\
& \text { 24.0d.XVIII. 102. 25.0d.XVIII. 239. 26.0d.XXI. } 240 .
\end{aligned}
$$
27.0d.XXI. 308 . 

course, placed the doors. If we assume that the "prothyron" had piliars, as is probable, then the inner portico was ldentical with the "althousa", a colonnade running on all four sides of the "aule".

\section{The "Aithousa".}

The "aithousa" is a colonnade around the inside of the "aule" next to the wall, or rather, in front of the rooms which have the wall of the "aule" as a common back. It is composed of a row of columns, supporting a roof, which ser serves to protect the front of these rooms, and to give them shelter from the sun and rain.

We know certainly that there is more than one "aithousa" in the "aule", because it is said, that in the house of Alkinoos, when the people of the Phaeacians were invited to the palace, the "althousai" and the "avle" were filled 28 , When Hektor goes into the palace of Priam, the palace is spoken of as being adorned with polished "aithousai" (29).

It is probable that there were "aithousai" on all pour sides of the "aule"; certainly there was a portico in front of the house, and another on the opposite side of the "aule", the one called the "aithousa" of the house, the other called the "althousa" of the "aule". I will speak of the former first, which stretches entirely across the front of the house. In it is arranged the bed of the stranger who may be a guest in the palace. At the house of Nestor a bed was prepared for Telemachos in the "aithousa" and he slept there during the night (30). At the palace of Alkinoos, when Odysseus arrived there, $a$ bed was arranged for odysseus in the "aithousa" (31). At the palace of Menelaos, we learn that Telemachos was entertained by Menelaos all Helen, and that the latter ordered her servants to arrange a bed in the "aithousa" for their guest (32).

Upon the other side of the "aule",opposite to this, is the "aithousa" of the "aule", extending along the front wall. A part of thio, the centre, is identical with the

$$
\begin{aligned}
& \text { 28.0d.VIII. 57. 29.II.VI. 243. 30.0d.III. 399. } \\
& \text { 31.0d.VII: } 336 . \quad 32.0 d . I V .297
\end{aligned}
$$



Inner portico of the "prothyron" of the "aule". Th1s becomes evident from the passage where Philoitios, when sent by Odysseus to lock or fasten the "aule" door, picks up a rope under the "althousa" and ties the door (33). The "prothyron" and the "aithousa" are linked together in many other passas ges, especially in connection with the trip of Telemachos and Peisistratos to sparta. For when they left the house of Diokles (34), the house of Menelaos (35), and for a second $t$ ime the house of piokles (36), it is stated in each case that they drove out of the "prothyron" and the "aithousa" . The same statement is made of Priam, when he left his house to go to the camp of the Greeks (37). We find also that the door of the "prothyron" is called the door of the "a1thousa" (38). This constant use of them together in the poem, shows that they are inseparable in fact, and this is natural when we consider their close relation.

Under the "aithousa" of the "aule" are tied the various animals that are brought from the farm to the house for the use of the suitors. Melanthios, the goat-herd, and Philoit1os, the cattle-herd, bring some of the animals, over which they have charge, to the palace, and tie them under the " "althousa", unt11 they are needed (39). It is also expressly stated that the bodies of the suitors were piled one on the other under the "aithousa" of the "aule",(40).

It has been stated that the "aithousa" is a row of columns. One of these is referred to in the odyssey, but its location can not be definitely deterinined. When the maids were hanged, in,order to facilitate matters Telemachos stretched a rope between the "tholos" and a lofty colum, presumably one in the "aithousa"(41). This pillar was in all probability in a corner, for it is stated that the maids were collected in a place whence they could not escape, and naturally it would be a column of the "aithousa" of the "aule".

The "althousa"1s, then, a row of columns, supporting a roof and extending around all four sides of the "aule", including on the front side the "prothyron", on the opposite side the "prodomos".

$$
\begin{aligned}
& \text { 33.0d.XXI.390. 34.0d.III. 493. 35.Od.XV. } 146 . \\
& 36.0 d . X V \cdot 196 \quad 37.11 . X X I V .323 . \quad 38.00 . X V I I I .102 . \\
& \text { 39.0d.XX. 1768 189. 40.0d.XXII.449. 41.0d.XXI1. 467. }
\end{aligned}
$$





\section{"Thalamoi" in the "aule".}

Back of the "althousa" at the sides of the "aule", are rooms, "thalamoi", the door-ways of whlch are protected by the "aithousa" from the sun and rain. We know that they were used as sleeping-rooms, and thay ptobably served as storerooms and work-rooms also. Here it is very probable that the suitors slept, those that did not live in Ithaca itself, and here they were joined by the unfaithfin servants of Penelope; for it is said that when Odysseus was sleeping in the "prodomos", before the door of the house, these servants came out of the "megaron", to join the suitors(42). It is stated that the palace of Priam was adorned with pol1shed "althousa1", and that in it were fifty "thalamoi", or chambers, of polished stone, which served as sleepingrooms for his sons and their wives; and across the "aule", opposite to them, were the twelve "thalano1" of his daught ters and their nusbands, of polished stone, built alongside of each other (43). This clearly establishes the fact that there were rooms in the "aule", used as sleeping-rooms. We have references made to still another "thalamos" in the "aule", that of Telemachos.

\section{The "Thalamos" of Telemachos.}

It is stated by Buchholz(44) and Protodicus(45) that the "thalamos" of Telemachoswas án isolated building in the "au1e". According to Perrot and Chipiez(46) the "thalamos" was behine the "aithousa", but in the second story; that is, they place at each side of the "aule" a two-story building, and in the upper story of one, theyplaces the "thalamos" of Telemachos. But both of these theorles are unlikely. It is much more likely that it was behind the "aithousa", like the other rooms, not on the second story but on the ground.

We have sufficient evidence to show that it was in the "aule". When Telenachos, at the bidding of Odysseus, had taken the arms out of the "megaron", he then departed to his own "thalamos" out through the "megaron" (4ף). Again, when

42.0d.XX. 12. 43.II.VI. 244,ff. 44.Homerische Realien,

Vol. Ir.sect.63. 45. De Aedibus Homericis, p.22.

46.H1stoire de l'Art, Vol.VII, p.83. 4r.0d.XIX. 48. 

he went to his "thalainos" at night, it is distinctly stated that he went to his "thalanos" where it was built in the "aule", In a conspicuous place (48). This last phrase is by Buchholz and Protodicus judged sufficient to warrant their theory of 1solation; by Perrot and Chipiez, to warrant their theory as to its location in the second story.

But both of these theories are too strained. It is not necessary to imagine a little one-room structure, isolated in the "aule"; we have, indeed, no other instance of 1 t. We have, however, instances of rooms in the "aule", which served as sleeping-roons, notably those at the palace of Priam, where the fifty rooms for his sons, and the twelve for his daughters, are placed opposite each other in the "aule". (49).

Nor is there any sufficient basis for the theory of location which Perrot and Chipiez concelve, that on the second story. For when we examine all the passages that mention Telemachos" "thalamos", we find in none of them any reference to ascent or descent, even when he is represented as going into his "thalamos", or when Eurykleia is said to leave it $(50)$. We see then, that neither of these theories is likely. The "thalamos" is located, therefore, in the natural place, behind the "aithousa".

An attempt has also been made by Protodicus(51) to show that the chamber of Nausicaa, daughter of king Alkinoos, was also in the "aule". He bases his arguments for this position on the passage where Nausicaa goes througn the palace to find her parents and tell them her dream. She finds both of them in the house, her mother by the nearth, and her - father just going out the door to the assembly of the old men of Phaeacia (52). This passage, which, according to Protodicus, proves conclusively that her "thalamos" was in the "aule", proves rather that her "thalainos" must have been located at the rear of the house, in the women's apartinents. For Nausicaa, when coming from her "thalamos", comes through the house directly to the "megaron", where she finds her mother, sitting by the hearth near the centre of the room, and then passed along to speak to her father, who was at the front door. She must then, have entered the rear door of

$$
\begin{array}{ll}
\text { 48.0d.I. 426. } 49 . I 1 . V I .263 . & 50 . \text { Od.I. } 441 . \\
51 . \text { De Aedibus Homericis. p.23. } & \text { 52. Od.VI. } 54 .
\end{array}
$$



the "megaron", the one leading into the women's apartments. Had she entered the front door, as she assuredly woild have done if her "thalanos" was in the "aule", she would have met her father first. When Nausicaa returns from the river with the clothes, she drives up to the door of the house, and goes to her "thalamos". Had her "thalamos" been located in the "aule", she would naturally have driven directly to 1t (53). The other passeges which relate to her "thalanos" prove nothing for elther theory, because the "thalamos" in: might be in the "aule" or in the house, as far as they are concerned.

But when we examine the probabilities of the case, it is very clear that the "thalamos" could not have been located in the "aule". In Homeric times the "aule" would not be a proper place for the "thalamos" of a young unmarried girl. It was very well for the "thalamos" of Teleliachos to be in the "aule", because he was a young man. But the "thalamos" of a young girl, the daughter of a king, would be located in the interior of the house, where that of her father and mother was located.

The Floor of the "Aule".

Enclosed by the "althousa", and the wall behind 1t, was the open court, a rather large space, containing several structures. The floor was made of natural earth, as is clear from several passages. In the palace of Menelaos, as Telemachos was leaving, an eagle flew'down and took a large goose out of the "aule" (54). It is likely that the fowls were kept in an unpaved yard: When Noemon, who had lent Telemachos a ship for his trip to Pylos, came to the palace to inquire for him, he found the suitors before the "megaron" on a levelled-off place, engaged in throwing the discus and spear (55). The term, "levelled-off", employed. here, implies that the rest of the ground was not level and paved, but of natural earth. Priam, when he had heard the
53. Od.VII. 7.
$54.0 \mathrm{~d} . \mathrm{XV} \cdot 160$
55. Od.IV. 625 

news of the death of his son Hector, is said to have rolled in the dirt and dung of the "aule" (56). In this condition Iris found him, when she came to the palace. Later, when Priam was talking to Achilies, he says himself, that he was rolling in the dirt of the "aule", in grief for his son.(57), Again, when Eumaios came to the palace, with pigs for the suitors, he let them run loose in the "aule", until the suitors should have need of them (58). The statement made here that these swine are allowed to run loose and graze in the "aule", proves conclusively that the "aule" generally had a dirt floor.

\section{The "Bomos", or Altar.}

We know that altars were common in Greece at this time, whether in connection with a house or not, from the fact that altars are mentioned in varlous connections all through the poems. Aegistheus, after seducing clytemnestra, made many burnt offerings of thanks on the altars of the gods(59). Odysseus compares Nausicaa to a palm-tree growing on the 1siand of Delos, near the altar of Apollo (60). After the return of Odysseus, when the ship of the Phaeacians was turned into a rock by Poseidon, the chiefs of the country of Phaeacia stood about the altar and sacrificed to the gods (61). On the 1sland of Ithaca, near the spring where the people of Ithaca drew their water, was situated an altar, where the passer-by made offerings (62).

But the altar of the house was situated in the "aule", probably in the midale. During the fight of Odysseus with the suitors, Phemios, the minstrel, seeking to escape the wrath of Odysseus, was undecided whether he should go out in the saule" and sit by the altar of Zeus, or should clasp the knees of Odysseus and beg for his life, finaliy deciding on the latter(63). Odysseus spares him and Medon, the herald, and tells them to go into the "aule" and sit apart from the flghting(64). They obey hiri, go into the "aule", and sit down by the altar of Zeus (65). This, called the altar of

$$
\begin{aligned}
& \text { 56.I1.XXIV. 164. 57.I1.XXIV.640. 58.0d.XX. } 164 . \\
& \text { 59.0d.III.273.60.0d.VI.362.61.0d.XIII.187.62.0d.XVII.210. } \\
& \text { 63.0d.XXII. 334. 64.0d.XXII. 375. Od.XXII. } 379 .
\end{aligned}
$$



Zeus "Herkeios", or Zeus of the "aule", furnishes us an additional proof of the existence of the altarthere. We learn in addition that Odysseus and Nestor, on their arrival at the palace of Peleus, found Peleus in the "aule", sacrificing to the gods (65). Here the altar is not expressly mentioned, but it is clearly understood. We see then, that the altar is located in the "aule", and probably in the midale.

We know little or nothing about the construction of the altar, but it was probably raised above the level of the ground, on a level with a man's walst.

\section{The "Tholos".}

In the enclosure of the "aule" was another building, the "tholos". It is inentioned in only two places, both of these in connection with the punishnent of the unfaithful women-servants. When Odysseus had conquered and slain all $t$ the suitors, wishing to punish also the women-servants who had been treacherous to him and Penelope, he told Telemachos to have them brought out of the house, as soon as they had cleansed the "megaron", and put in a place between the "6: "tholos", and the "aule" wall(66). They are accordingly brought out, and placed in a corner whence they could not possibly escape(67). Then a rope was stretched between the "tholos" and a large pillar (68), and by this means they were hanged. This constitutes our knowledge of the "tholos", rather linited it would seem, yet it is possible to draw some conclusions as to its position.

About 1ts appearance we know little. It was probably dome-shaped and not very large in circumference. The pillar mentioned in the passage, must have belonged to one of the "aithousa1". Further it was in a confined place from which the women could not escape, probably a corner. Hence it was probably located in one of the four corners of the "aule". But we know that next to the "aule" wall, between $1 t$ and the house, was a passage-way, on one side ats least of the "aule", possibly on both. The "tholos", then, was probably not located on the house side of the "aule", sine the women could easily have escaped down the passage. This ieaves the

65. II.XI. 774. 66. Od.XXII. 44I. 67. Od.XXII. 459.

68. Od. XXII. 467 . 

other two corners, in front. It was probably located in one of these.

Buchholz(69) gtves this location of the "tholos" and furhter says that $1 t$ was used for holding articles of daily use, such as farm implements and house utensils. This might be a very good use to put it tos but we have no evidence from Homer with regard to its us.

Perrot and Chiplez(70) do not advance any theory as to the ptobable use of the "tholos", but they have definite ideas as to its location. They place the "tholos" near the "megaron" on the left as one comes out, in a small enclosure, which has obviously been constructed with the holding of the women in view, since it has only one outlet. The "tholos" itself is represented as a circular, dome-shaped building, rather small in circumference, placed on a high base, upon which one climbed by means of a flight of steps. Not far from the "tholos" is placed a colurin, situated in a very convenient position for hanging the woinen, but apparently used for no other purpose. Telemachos is represented as climbing up on this base, and attaching the rope to the "tholos", and then tying the rope high up on the pillar by means of a ladder. This whole arrangement has apparently been thought out with view to making arrangements there especially for hanging women-servants. But we cannot accept such a theory.

\section{The Uses of the "aule".}

The number and kind of uses to which the "aule" was put 1s remarkable. But when we consider 1ts position, accessitb111ty and impottance in the house, we can better underst stand the varied'uses of the place.

It was used first of all as a place for recreation, since through its size it was readily adapted for games. When Athene, in the guise of Mentes, came to visit the house of Odysseus, she found the suitors seated in the "aule" on skins, playing a gaine of "Pesso1", presumably a sort of checkers(71). Somewhat later, after Telemachos' departure to

69. Homerische Realien. Vol.II. sect. 63. 70. Histoire de l'Art. Vol. VII. p.84. 71.0d. I. 103 . 

Pylos, Noemon, who had lent him the ship for his voyage, came to the palace and found the suitora there before the palace, engaged in throwing the discus and javelin, on a levelled-off place that had been used before purpose (72). Th1s passage seems to infer an habltual use of the "aule" for such sports, and indeed 1t was the natural place for such recreation.

Here in the "aule" also, the animals were slaughtered both for sacrifice and for the table. At the house of Nestor, a very elaborate sacrifice was conducted under the direction of Nestor himself, as he sat in the "aule", just before the palace doors (73). The animal is brought from the fields, her horns are gilded, and she 18 struck down by Thrasymedes. This leaves no room for doubt, since Nestor's position is given so clearly.

In the palace of Odysseus the slaughtering of goats and swine for eating, is shown even more clearly to be in the "aule". Telemachos, coming to the palace from the seashore, after praying to Athene, finds the suitors within the confines of the palace, flaying goats and singing swine in the "aule" (74).

We know also that here in the "aule" the horses were yoked to the chariots when anyone was going on a journey, and that they had their stables in the "aule", where the charlots were also kept.

We have repeated references to chariots' driving out of the "aule", passages which seem to imply quite strongly that the actual harnessing of the horses had been perforrned in the "aule" itself. These passages usually contain the statement, "And they drove ont of the "prothyron" and the "aithousa"." This statement is made in the account of Telemachos' journey to Pylos, when he leaves the house of Dlokles (75), the house of Menelaos (76), and when on his return he leaves the house of Diokles for a second time(77). This statement 18 also used in describing Priam's departure from his palace, when he goes to the camp of the Greeks, to ransom Hektor's body $(78)$.

$$
\begin{aligned}
& \text { 72.0d.IV. 625. 73.0d.III. 418-464. 74.0d.II. } 300 . \\
& 75.0 \mathrm{OdII} \cdot 493 . \quad 76.0 \mathrm{~d} . \mathrm{XV} \cdot 346 . \quad 77.0 \mathrm{O} . \mathrm{XV} \cdot 191 . \\
& \text { 78.I1.XXIV. } 323
\end{aligned}
$$



There are also passages that describe at some length the harnessing of the horses in the "aule". When Telenachos was leaving the house of Nestor(79), we have described for us the yoking up of the horses, and while it is not stated where the harnessing takes place, the presumption is that $1 t$ was in the "aule". In the palace of Alkinoos also mules are hitched to the wagon of Nausicaa, so that she may carry the clothes to the river $(80)$. Here it is not distinct= ly mentioned that the mules were harnessed in the "aule", yet since the clothes are brought directly froin the house to the wagon (81), we may safely assume that they were in the "aule". At the palace of Menelaos, also, Teienachos and Peisistratos come out of the house from their meal, harness the horses, mount their chariot, and drive out of the "prothyron" and the "aithousa" (82). They drive out of the "aule" here, at any rate, and as we have no mention of their being harnessed and then brought into the "aule", it seems quite clear that they were harnessed in the "aule".

But in the palace of Prialn we see this proved even more clearly. Fot first we have the harnessing of the horses described in detail (83). Then the team 1s spoken of as standing harnessed "within the lofty house", which shows that the operation must have taken place within the limits of the palace (84). And finally, to complete the evidence, he drives out of the "aule" to the camp of the Greeks (85). By taking all these different passages together, and comparing them, we see clearly that both here and in other palaces horses were harnessed in the "aule".

But besides being harnessed in the "aule", we have conclusive evidence to show that horses were actually stabled there, and the charlot kept there ready for use. But in spite of the evidence in the Homeric poens as to the location of the horse-stalls in the "aule", Protodicus (86) and Buchbolz (87) nold a different view. They have attempted to show that the stables were in a yard at the back of the house, although there is no evidence for such a theoty in the Homeric poems. The "Inychos" of the house is by them regarded as a back-yard, and narked of $f^{\circ}$ a a separate enclosure. But "mychos", in the sense used in Homer, means merely the interior part of anything, whether a house, a

$$
\begin{aligned}
& \text { 79.0d.III. 493. 80.0d.vI.73. 81.0d.VI. 74. } \\
& 82.0 d . X X .145 . \quad 83 . I I . X X I V .265-275 . \\
& \text { 84.I1.XXIV.281. 85.II.XXIV. 323. 86.De Aedibus } \\
& \text { Homericis. p.bl. 87.Homerische Realien. Vol. Ir. sect.74. }
\end{aligned}
$$



room or a cave. The mychos of a house is the interior part of the house, not a yard at the back, outside of 1t. (For full discussion of the meaning of "Inychos", see page 44).

Their principal reason for placing the stables here instead of in the "aule", is that it would not have been nice to have the stables in front, in the "aule". But this argument is not valid, since we know that in the palace of odysseus a dung-heap was located ${ }^{\text {the }} 87$, , while it is also distinctly stated that Priam rolied in the dirt and dung of the "aule", in grief for his dead son Hektor (88). Furthermore we know that cattle and other aniluals were slaughtered in the "aule".

Then, too, we know that fowls were kept in the "aule". Geese were kept at the palace of Odysseus, since Penelope mentions them in the dream which she relates to Odysseus(89) We know also that geese were kept in the "aule" of the pal -ace of Menelaos, because when Telemachos was taking his departure, an eagle flew down, and seized and carried away a large tame goose from the "aule" (90). We hear also of other animals in the "aule". Both Melanthios and Philoitios, the one bringing some of his goats (91), the other, some of his cattle (92), come to the palace and tie the animals -under the "althousa". Eumaios, too, bringa in some swine for the sultors, and lets them run loose in the "aule", until needed (93). This then disposes of the arghment on the ground of nicety, since there is no reason to believe tnat stables ould be excluded from a place of this kind.

We have several passages to show that the stalis of the horses were in the "aule". When Nausicaa enters the "aule", on her return from the river with the clothes, she drives up to the "prothyron" of the house (95), where her wagon is unloaded and her mules loosed fron the yoke. It is true that there is no explicit statement that the mules are stabled here, yet they are unharnessed right at the door of the house, and it is only fair to assume that they were lead to their stalis in the "aule". Again, when Hera and Athene were callud back by Zeus from giving assistanee to the

$$
\begin{aligned}
& \text { 88.XVII. 297. 89.II.XXIV. 161. 90.0d.XIX. } 552 . \\
& \text { 91.0d.XV. 160. 92.0d.XX. 276. 93.0d.XX. I79. } \\
& 94.0 d . X X .164 .95 .0 d . V I I .7 .
\end{aligned}
$$



Greeks, they five the chariot over to the Horae, who loose the horses, tie them at their immottal stalls, and lean the charlot against the "enopia"(96). The "enopia" are the faces of the walls on either side of the doorway of the house. So these horses of the gods are unharnessed in the "aule", lead to their stalls in the "aule", and the chariot is ieaned against the front of the house.

The most conclusive evidence is afforded us in the passage in which is described the arrival of Telemachos and Peisistratos at the palace of Menelaos. For when they drove up, they stopped at the "prothyron" of the house, hence in the "aule"; then the horses were taken out of the char 1ot, led to the stalls, tied there, and fed barley and spelt, while the chariot is tilted up against the shining "enop 1a"(97). Now this operation must have taken place in the "aule", because it is said that they stopped their horses at the "prothyron" of the house. We know that there was an "aule" at the house of Menelaos, because at the departure of Telernachos, an eagle flew down near where Helen and Menelaos were standing by the chariot, and seized a large tame goose out of the "aule"(98). In the absence of any statement that in any case horses were taken to the back- yard, and in the face of the above evidence, the conclusion is inevitable that the stalls of the horses were located in the "aule".

Perrot and Chipiez (99) place at the front of the "aule" a row of atalls for the cattle and other animals, and in front of the stalls a fenced-in enclosure for confining them froin the rest of the "aule". There is no authority for such a cattle-pen in the "aule". When Nestor wished an animal for sacrifice, he had a heifer brought froin the figlds(100). Again, when animals are brought and kept at the palace for a time, they are not put into such enclosures as are assumed by Perrot and Chiplez. When Cattle are brought to the house by. Philoitios, he does not place them in a cattle-pen in the front of the "aule", which he undoubtedly would have done, had there been such a pen, but

96. Il.VIII. 434. 97. Od.IV. 39. 98. Od.XV. I62.

99. H1stolre de l'Art. Vol. VII. p. 83. 100. Od.III. 430. 

the statement is distinctiy made that they were tied under the echoing portico. When Melanthios brings goats to the palace for the use of the suitors, they are also tied under the echoing portico.

They place the pig-pen at the side of the house, in a separate enclosure, with a passage leading into the "aule". He calls this the"herkea", and says that when it is stated that Eumaios turned his pigs loose to feed in the "herkea", this side enclosure is the place referred to. But we do not find the word, "herkos", or its plural, "herkea", used with the significance of an enclosure different from the "aule". The word means a wall around any thing, and then comes to mean the enclosure which is surrounded by the wall. Since it means the wali of the "aule", It has come to be used with the meaning of "aule", and "herkos", "herkea" and "aule" are synonymous. We find "herkos" used in the meaning of wall in several places. On both sides of the garden of Alkinoos there was a "herkos"(101). When the women-servants were executed, they were held between the "tholos" and the " "herkos" of the "aule"(102). These will suffice to show the ortiginal meaning. Other passages will serbe to show the det rived meaning. It is said that at a meeting of the Phaeacians, at the house of Alkinoos, the "althousa1, the "herkea" and the rooms of the men were crowded (103). The only possible meaning of "herkea" here is trie "aule".

Again, Eumaios leaving the palace, is said to leave the "herkea" and the "inegaron" (104). Surely the pig-pen would not be spoken of in connection with the main living-room of the house. When the "thalamos" of Odysseus is described, it is sald that it was built around an olive-tree inside of the "herkos" (105). During the fight with the suitors, the women were warned not to come"out if they heard any noise inside of the "herkea" (106). And, last of all, Priain stood in the midale of the "herkos", and poured a libation to Zeus just before his departure to the camp of the Greeks.(107). From any of these passages it is clear that the "herkea" can not be a separate enclosure for the pigs. For in none of the them can it mean any thing else than the "aule".

$$
\begin{array}{lll}
\text { 101.0d.VII. 112. } & \text { 102.0d.XXII.469. } & \text { 103.0d.VIII. } 57 . \\
\text { 104.0d.XVI. 341. } & \text { 105.0d.XXIII. 190. } & \text { 106.0d.XXI. } 384 . \\
107 . I 1 . X X I V .306 . &
\end{array}
$$



The House Proper.

Passing fror the "aule" of the house", we coine to the house proper, that part of the establishinent which is roofed over. In the front part of the house are situated the men's apartments, which consist of one large room, called the "megaron", opening into the "aule". Back of this are the women's apartments, which contain the living-rooms and sleeping-rooms of the woilen. About the arrangement of this part of the house we know very little. The house has also an upper story, extending over the "megaron" and probably over the whole house, where other apartinents of the women are located.

\section{The "Prodomos".}

Inmediately before the front door of the house is the "prodoinos,", or "prothyron" of the house. It is known by both names, but since we have another "prothyron", the entrance to the "aule", the term "prodomos" is less ambiguous. As to the exact form of the "prodomos" we are notexty certain, because the exidence from the poems gives no conclusive proof. It may have been a shaliow vest1bule, leading into the "megaron". This is the f'orm we find at Tiryns and at other ancient palaces. There is some evidence to support this theory, and also to show that there were columns between antae in the "prodoinos". When Telemachos, coming from the hut of the swineherd, upon his return from Pylos, reached the palace, he leaned his spear against a colum, and entered the doorway (108). This was ptobably one of the columns at the front of the "prodomos". The colurin is evidently near the front door, and may have been one of the columns at the front of the vestibule.

108. Od. XVII. 29. 

But since it is identified so completely with the "althousa", It is just as likely that the door of the palace opened directly into the "althousa" oandethat there was no separate vestibule. Furktermore the column referred to in is the passage above, may have been one of the columns of the "aithousa". In this case the word, "ptodomos", is the name for that part of the "aithousa", which lies directly before the door, and there is no definite boundary. In either case however, the "prodomos" would le readily and naturally identified with the "aithousa".

As has been sald, it is located immediately before the "megaron" door, so that one going froin the "aule" into the house, lust go through it. We see this first of all from the speech of Theoklymenos. He, when the suitors were seated in the "megaron", prophesied death to them, teliing thein that the walls were dripping with blood, and that the "prothyron" and "aule" were filled with ghosts (109). This shows us the relation of "ptodomos" and "aule" to the "megaron". But we get a clearer indication in the following passages. When Futytion, a Centaur, tried to do:injury to the house of Perithoos, the heroes in anger dragged him out-of-doors through the "prothyron"(110). This shows clearly that there was a "prothyron" before the door. Again, when the suitors had been slain, and the women executed, Melanthios was brought out of the house, through the "prothyron" and "aule" and killed (111). But the clearest indication,perhaps, of the relation of "aule", "prodomos" and "megaron", can be veen from the fight between Iros and odysseus. For odysseus, when he had once conquered Iros, dragged him out of the "megaron", through the "prothyron", into the "aule" (112). This leaves us in no doubt as to the location of the "prothyron" of the house.

The "prothyron" is also identicad with that. part of the "althousa" which lies directly in front of the nouse. So closely in fact are these connected, that the terms, "aithousa" and "prodoinos" are used indiscriminately. We have passages, even, in which persons are represented as going to sleep in the "althousa" and waking up in the "prodomos". At the house of Menelaos, for instance, a bed was prepared for Telemachos, and Pelsistratos, in the "albuousa" (113). Immediately after, they are spoken of as sleeping in the "prodomos"(114), and when they wake up, they are said to

$$
\begin{aligned}
& \text { 109.0d.XX. 355. 110. Od.XXI.296.. 111.0d.XXII. } 474 . \\
& \text { 112.0d.XVIII. 101. 113.0d.IV. 294. 114.0d.IV.302. }
\end{aligned}
$$



be in the "prodomos" (115).

In this connection, we mat take up the uses of the "prodomos", apart from 1ts use as an entrance. We find it used very often as a place to sleep in, always, however, as a sleeping-place for the guests at the palace. At the palace of Menelaos, a bed was prepared for Telemachos and Peisistratos in the "prodomos" (116). Odysseus, still in the guise of a beggar, refused to sleep inside his own house (117), "But slept in the "prodomos" on hides and on skins (118).

In at least one palace tnat we know of, tables for dining were placed in the "prodomos" and left there after the banquet was over. This occurs in the palace of Ktesios, the father of Euliaios. For the woman that kidnapped Eumaios stole, on her way to the ship, thres cups from the tables that were set in the "prodomos" (119). But this is the only instance that we know of , of such a use on the "prodomos". In connection with the "prodowos" we may as well take up the "enopla". The "enopla" are the faces of the walls on each side of the doorway, literaliy those parts that are "In the eye" as one approaches the door. So they may be either inside or outside, as this description fits both. It was thought that they might mean the parts of the door between the door-posts themselves, but we can easily see tha that they do not apply to that part.

We meet this first in connection with the unharnessing of horses. Hera and Athene, called back by Zeusfrom assistIng the Greeks, give thelr charlot over to the Horae, who loose the horses and place them at their stalls, and lean the chariot against the shiming "enopia"(120). A similar passage 1s that deseribing the arrival of Telewachos and Peisistratos at the palace of Menelaos. Their chariot is also leand against the shining "enopia", after the horses have been loosed and led to the stalls (121). In both cases the chariot is leaned up against the side of the house, near the door.

The part of the wall inside the "megaron", on either

$$
\begin{aligned}
& \text { 115.0d.XV.5. } \quad 116.0 \mathrm{~d} \cdot \mathrm{IV}: 302: \quad 117.0 \mathrm{~d} \cdot \mathrm{XX} \cdot 143 \\
& \text { 118.0d.XX.1. I19.0d, XV.466. 120.Id.VIII. \$34. } \\
& \text { 121. Od.IV. } 42 \text {. }
\end{aligned}
$$



side of the door, is likewise called the "enopia". When the' arrows of Odysseus were exhausted, he leaned his bow up' against the door-post, against the shining "enopia"(122). Frola this passage alone some consider "enopia" to mean the interior of the doorway. But frow the passage concerning the chariots, 1t is clear that this meaning is impossible, since if the chariot were leaned against the inside of the door, it would block the passageway.

\section{The entrance to the "Megaron".}

The doors in a palace of Homeric times were apparently constructed in a manner very like those of today. They usually had two leaves, and they always had door-posts at the sides, a threshold under them, and a lintel above. In the palace of Alkinoos, the doors were said to have been of gold, the door-posts and lintel of silver, while the threshold was of bronze (123). These doors had goldeh handles on them also. While this was the palace of an exceptionally rich king and doubtless contained many articles of gold and silver, we can hardly believe that the doors were of solid gold, with posts and lintels of silver. They were in all probability made of wood, ornanented with these metals. But oven this ornamentation would be found only in the palace of a very $\mathrm{rich} \mathrm{king}$, and this description can not be taken as the model of an average house. Usually the doorleaves were of wood. merely, while we have it stated that the threshold and door-posta are of wood, In the case of the front door of the palace of Odysseus (124). The doors could also be locked by means of a thong and bar. This we learn from the description of the door of the "thalamos" of Telemachos (125).

Opening directiy from the "megaron" into the "prodomos" is the front entrance of the house, the door of the "megaron", located probably at the middle of the front part of the house. It was furnished with double doors, which hung between door-posts, and rested on a rather broad threshold.

$$
\begin{array}{ll}
\text { 122. Od.XXII. 121. } & \text { 123. od. VII. } 88 . \\
\text { 124. Od. XVII. 339. } & \text { 125. I. } 441 .
\end{array}
$$



We know that the doors were double, because they are always spoken of as the "doors", never as the "door", in all the referances made to thern. When odysseus cane to the palace, in the guise of a beggar, he sat down on the threshold, inside the doors (126). When Iros came and tried to put him out of his place, it is said that they sat before the doors and disputed (127). We have many other passages to the same effect, and in none of them do we find the word, "door", used in the singular (128).

These doors are set on thresholds of ash or stone and hurig between door-posts of wood. In this case we find that cypress wood was used in the door-posts. When Odysseus first came to the palace, it is said that he sat down on the ash threshold and leaned against the cypress door-post (129). This shows quite clearly the materials used in the construction of the doorway. But there is another passage that seems to show that the threshold of the front door of odysseus' palace was of stone, and not of ash. When Telemachos cane to the house, after his return frola Pylos, he leaned his spear against a p1llar in the "prodornos", crossed the stone threshold, and went in to see his mother(130). This certainly refers to the threshold of the front door, but it is very difficult to reconcile the two passages. We, have, however, the stone threshold mentioned a second time; "for Telemachos, bringing Odysseus into the "megaron", gave him a seat near the stone threshold (131). This seems to support the idea of the stone threshold, since we find no other mention of the ash in the pazaeeod odysseus.

The epithet, "xestos", nor "polished", is applied to the tbodshold, but this would show the material, since both wood and stone may be polished. During the fight with the suitors, Eurymachos says that odysseus w11I stand on the polished threshold and k1ll them all (132). It is also stated that Iros and odysseus were quarreling on the polished threshold, before the doors (133).

the The threshold rust alave been quite large, for this is

126.Od,XVII. 339. 128.0d.XVIII. 32. 128. See Od.I. 255 XXII. ry6; XXII. 91; XXII. 250; XVII. 530. 129.0d.XVII. 339 . 130.0d.XVII. 30. 131.0d.XX. 258. 132.0d.XXII. 72. $133.0 \mathrm{~d} . \mathrm{XVII} .33$. 

probably the most 1mpottant and the largest doorway in the house. We find evidence for such a belief. When Iros tries to make Odysseus leave his seat, the latter says that the threshold is large enough to nold then both (134), and later they both sit on 1 t and quarrel (135). But the best evidence is thst the threshold is called "large", direcily. For odysseus, when he was about to kill the sultors, hastened to the large threshold, and took his stand upon it (136).

\section{The "Megaron".}

The "megaron" is the large rooin of the house, situated in the house proper, in the front part, with a doorway opening into the "prodomos" and thence into the "aule". We see this relation very'clearly froil Nausicaa's speech, when she is giving directions to odysseus, for coining to her home. She says that when the palace and the "aule" have recelved him, he is to enter and pass through the

"hegaron" (137). She speaks of his coming to the house, "domos", first, and then mentions the "aule" and "megaron" in order. We can get a somewhat clearer idea of the exact relation of the "aule" to the "megaron", from the passage where Odysseus drags Iros out of the "Inegaron", through the "prothyron", and then into the "aule" (138). It is evident, therefore, that the "liegaron" is the first room entered, when one passes from the "aule" into the house.

The "megaron" is a large room, though we do not know its exactdimensions, in ali probability rectangular in shape. It served as the living-rooin of the house, and was used for a variety of things. The contents of the "megaron", and its manner of construction, both need to be exainined, so that we may get an idea of the whole.

$$
\begin{aligned}
& \text { 134. Od.XVIII. 17. 135. Od.XVIII. 33. 136. Od.XXII.2. } \\
& \begin{array}{ll}
\text { 137. Od.VI. 304. 138. Od.XVIII. 101. }
\end{array}
\end{aligned}
$$



The Walls of the "Megaron".

The material, of which the walls of the "megaron" were made, 18 nowhere ststed,; indeed, we have only one passage which mentions the material. It is said, that in the house of Alkinoos the walls were of bronze (139). Here too, as in the case of doors, door-posts, etc., this expression does not mean that the walls were of solid bronze, but merely decorated with that aterial. But king Alkinoos was said to have been very wealthy, and his house was richly decorated, so we cannot take his palace as the type. It is not likely that an ordinary king had walls decorated with bronze in his house.

The walls are mentioned in various connections. Ktessipos threw an ox-hoof at odysseus, as he sat in the doorway, but missed him and struck the wall (140). Again, when the suitors got their arms and threw spears at Odysseus, they did not succeed in hitting him, but struck the door and wall(141).

We learn also that weapons were hung on the walls. The suitors wished to defend themselves against the arrows of odysseus, and looked along the well-built walls for the weapons that'usually hung there (142), but they did not find any, because Odysseus and Telemachos had reinoved them all on the previous night (143).

We also find the walls inentioned in connection with the roof or the supporting beams. Theoklymenos says that the walls and cross-beams of the "megaron" are covered with blood, and the "aule" filled with ghosts(144). Teleliachos, when assisting his tather to carry the weapons out of the "inegaron" says he sees a light on the walls and pillars and supporting cross-beains (145).

The walls of the palace at Tiryns, were built of stone for a short distanee up, and then the rest of the wall was composed of sun-dried brick. This lnay have been the mehtod of structure for the walls of the Homerlc house also.

$$
\begin{aligned}
& \text { 139. Od.VII.86. 140. Od.XX.302. 141.0d.XXII. } 257 . \\
& \text { 142. Od.XXII. 24. 143. Od.XIX.31. 144. Od.XX. 354. } \\
& \text { 145. Od.X2x. } 37 \text {. }
\end{aligned}
$$



The Floor of the "hegaron".

From the expressions that are used to describe the floor of the "megaron" we know that it was of natural earth. We constantig fing expressions used that denote "ground", or "earth". In the palace of Agamemnon, when he was treacherously killed, It is said that he lay in the "megaron", and the floor ran with blood (146). The word, "dapedon", is used to signify the floor, and this regulariy ineans "ground". In the palace of Odysseus, during the fight with the suitors, Leokritos, one of the suitors, fell, and struck the floor with his face (147). Here the word, "chthon", is used, which means "ground", or "earth". Penelope bids odysseus sleep in the house, when he is there disguised as a beggar, elther on the floor or on beding (148). The floor here is indicated by means of the word "chamadis", which lileans,"on the ground". Again, the servants, replenishing the fire in the "megaron", threw coals froln the braziers onto the floor, and piled fresh logs on the braziers (149). This confirms our theory, ahd besides, the word "chamadis" is again used.

But perhaps the most convincing proof of the material of the "luegaron" floor, is contained in the passage where Telemachos digs a trench to set the axes in. For he sets up the axes ina long trench, which he digs in the floor, in a straight line, and then tamps the earth, "gaia", in around them(150). inis shows clearly that the floor was of earth.

\section{The "Eschare", or Hearth.}

In the "megaron" of the Homeric house was located the hearth, a fact which we learn from several passages. It is sald that at the house of Odysseus, when Odysseus came out of the "megaron" in the morning, the women were building a fire at the hearth(151). Nausicaa, coning into the "megaron" of Alkinoos from the rear part of the house, to find her parents, comes upon Arete sitting at the hearth, spinning (152). Again at the house of Alkinoos, Nausicas directs odysseus to go through the'"megaron" until he comes

$$
\begin{aligned}
& \text { 146.0d.XI.420. 147.0d.XXII. 196. 148.0d.XIX. } 599 . \\
& \text { 149.0d.XIX.63.ff. I50.0d.XXI. } 120 . \\
& 151.0 d . x x .123 . \quad 152.0 d . V 1=52 \text {. }
\end{aligned}
$$



to her mother, Arete, who is sitting by the hearth, weaving in the light of the fire (153). Odysseus follows these directions, and when he has implored aid of Arete, he sits down by the hearth in the ashes(154). We see clearly that th the hearth was located in the "Inegaron"

The hearth was used for furnishing light and heat. When Penelope came to speak to Odysseus, who was still in the guise of a beggar, she had a seat placed for herself near the fire in the "megaron"(155), and the servants replenished the fire in the braziers, which evidently served as a hearth, by throwing fresh wood on the coals(156), so as to give light and warmth. In the palace of Alkinoos, when coysseus enters the "megaron", he finds Arete at the hearth, weaving a wonderful purple cloth by the light of the fire (157). With such clear and explicit statements as to the use of the hearth, it is very evident that it did serve to furnish light and heab.

It is somewhat more difficult to decide about the appearance and construction of the hearth, since nothing is said on those points. In the "megaron" of Odysseus we h hear of braziers being placed. For the servants threw some fire on the ground from the braziers, and piled fresh wood on them (158). Apparentiy, however, these braziers are moveable affairs, not permanently fixed in position.

The hearth of the "megaron" in both the palace of Tiryns and of Mycenae, is circular in shape and rather shallow, and is separated from the rest of the floor by a ridge of cement. This arrangenent would hardly be sultable nere, since the floor was not of cement but of natural earth, and the hearth could not be so clearly marked. Probably on this account the braziers were used in the house of Odysseus, and set up in the "megaron" to hold the fire.

The hearth was probably located at the centre of the "megaron". this is partiy shown by the fact that odysseus, when entering the "megaron" of Alkinoos, passed along throug the room until he came to Arete, who was sitting near the hearth(159). Its location in the centre is further shown by the fact that in the palaces of Tiryns and Mycenae the hearths are exactiy in the centre of the space formed by the four supporting columns, arranged in a square.

$\begin{array}{lll}\text { 153.0d.VI..305. } & \text { 154.0d.VII. } 153 . & 155.0 \mathrm{O} . \mathrm{XIX} .55 . \\ 156.0 \mathrm{X} . \mathrm{XIX} .63 . & 157.0 \mathrm{Od} . \mathrm{VI} .305 . & 158.0 \mathrm{O} . \mathrm{XIX} .63 .\end{array}$

159.Od.VII. $14 i$. 

The Pillars of the "Megaron".

The "megaron", because of its size, must necessarily have had columns to support the roof, and we do find references made to them, usually in each case to some one pillar. Thus, when Telenachos brings Athene, in the guise of Mentes, into the "megaron", he takes her spear and sets it In a polished spear-stand, against a lofty piliar (160). When Theoklymenos and Teleinachos come into the "ruegaron", just after the return of the latter from Py 10s, Penelope comes into the "megaron", and sits opposite them, as they are eatong, leaning against a pillar of the "megaron" (161). The exact location of neither of these columns is given, but columns in the house of Alkinoos are mentioned inore exactly. Pontonoos leads the minstrel, newodokos, into trie midst of the guests in the "megaron", and seated him in a chair, against a high pillar (162). And Nausicaa, in giving directions to Odysseus, says he will find Arete, her mother, sitting by the hearth in the "megaron", leaning against a pillar (163). This, then, determines the location of two columns, at least, in the "Inegaron", and both of these were near the centre of the room.

It may be advisable to state here, that.there were four supporting columns in the "megaron" of the palace of Tiryns, and also of that of Mycenae, and these were arranged in a square, rather toward the centre of the room, w1th the hearth exactly in the middle.

We find the columns spoken of also as a whole. Telenachos, when assisting his father to carry the arins out of the "megaron", teils Odysseus that the cross-beans, and the supporting pillars are covered with light (164). In every case we notice that the columns are called lofty, or h1gh.

The arrangement of the coluins is uncertain. The theory has been advanced by Gerlach (165), that the columns were arranged like those in the interior of a temple, that is, in two rows, with a large central space. This, it is true, would allow more space for the tables of those dining in the "megaron"; but he has placed the columns very near the wall,

$$
\begin{array}{lll}
160.0 \mathrm{~d} .127 . & 161.0 \mathrm{~d} . \mathrm{XVII} .96 . & 162.0 \mathrm{~d} . \mathrm{VIII} .66 . \\
163.0 \mathrm{~d} . \mathrm{VI} .307 . & 164.0 \mathrm{~d} . \mathrm{XIX} .37 . & 165 . \mathrm{Ph1} 1010 \mathrm{gus} .
\end{array}
$$

Vol.XXX.pp.503.ff. 

with none in the middle. We, however, know absolutely of the existence of a colum in the centre of the room. His arrangement, therefore, would not be in accordance with the facts.

\section{The "Orsothyre".}

The passage in which we meet the "orsothyre" is one of the most difficult passages to explain in the Odyssey, in relation to the construction of the house. We have it ment. tioned only three times, and these are all in the same book and all equally vague. It is generally supposed to be an opening, or doorway, in the wall, above the ground. Its threshold is probably on the level with the top of an! ordinary door, and it opened on the outside of the "megaron".

It is first mentioned duting the fight between odysseus and the suitors, and the passage reads, "There was an 'orsothyre' in the well-built wall, and by the highest threshold of the firmly made "inegaron' there was an entrance 1to a 'laure', a passage-way, and well-fitting doors closed this (166)."This clearly indicates that the opening was through the wall, and the expression, "by the highest threshold", means on a level with the lintel, and hence ralsed above the ground. Consequently, there must have been stairs or steps leading up to it. This is shown in the next reference made to it. For Agelaos, one of the suitors, asks Melanthios if it were possible for one to mount to the "orsothyre" and warn the townsmen (167). The expression, mount, or go up, is used here, and shows that it must have been necessary to ascend some stairs to'get to the "orsothyre".

In answer to the question of Agelaos, Melanthios,replies that such a thing would not be possible, for the beautiful doors of the "aule" are terribly near, and the mouth of the "laure" is narrow, so that one strong man inlght hold all of them back (168). We see, then, thatthe "orsothyre" opened

166.0d.XXII. 126. 167.0d.XXII. 132. 168.0d.XXII. 138 . 

into the "laure", which, in turn, opened upon the "aule" by a narrow entrance.

We have additional evidence to show that one could

pass through the "orsothyre", and thus go directiy into the "aule". Phemios, the minstrei, stood in the "megaron", right by the "orsothyre", and considered whether 1t would be better to go out of the "megaron" and sit by the altar, or beg his life of Odysseus, finally deciding upon the latter plan(169) Now we know that the altar was in the "aule", so the plan of Phemtosimast have been to ascend to the "orsothyre", go into the "laure", and thus get into the "aule".

J. H. Middleton (170) has the following theory about the arrangement of the "orsothyre". Ho says that.the "orsothyre" was an elevated door, with a stair leading up to it, and opening into the "laure", which is divided into two passages the one above the boher, since a mezzanine roof must have been placed in there, because the celing was too high for such a narrow passage. This "laure", then, opened directly into the "aule", not far from the door of the "lnegaron", where Éuma1os was sent by Odysselis to guard 1t, and to let no one go through $(171)$. He says, also, that the "orsothyre" was at the back of the "Inegaron", away froin the place where Odysseus and his companions stood, and Eumaios stood on the outside of the "megaron", and was in a position either to check thdse going out, or to help Odysseus. A part of this theory is probably correct, but it is much more likely that Eumaios was stationed inside to guard the"Orsothyre", and join in the fighting, than that he was placed so as to guard the'entrance of the "laure".

There is another theory stated by him also. This is, that the "way.into the passage" mentioned above, is separate and distinct from the "orsothyre". This "way into the "laure'"1s thought to be an entrance-way into the "laure", from the end of the "Inegaron" near Odysseus, and here odysseus stationed Fumaios, to prevent escape through the "laure". But this theory 18 shown to be incorrect, from the fact that it is clearly stated, that the "orsbthyre" is the only entrance to the "laure", in the passage where the "orsothyre" is first inentioned (172).

169.0d.XXII. 333. 170. Journal of Hellenic Studies.

Vol.VII. pp.161-169. 171.0d.XXII. 129.

172. Od.XXII. 130. 

Protodicus (173) conceives of the "orsothyre" as affording a passage either to the front or the back of the rouse, and through here he says Melanthios went to the back of the house, of course traversing the "laure", and brought the weapons back from the storeroom (174). This of course is mere assumption.

These theories are all probably partiy correct. The "orsothyre" is probably a door in the wall, above the level of the ground, to which access was had by steps. Inis led to a "laure", which was on the same level as the floor of the "megaron", and so there must have been steps leading down into the "laure", outside. The evidence is not sufficient to enable us to ascertain the exact location of the "orsothyre", and it is impossible to ascertain or decide anything absolutely.

The "laure", into which the "orsotinyre" af'forded access, was a passage between the wall surrounding the whole enclosure, and the wall of the "megaron". and extended froln the back, to the front of the house, allowing exit in either direction. We are sure that first, Telenacbos, and later, Eurnaios and Philoitios, traversed the "laure" to go to the storeroom. Telenachos left his father at the doorway, and hastened to the storerooin to get arms (175), returning without any groat delay, and it is uanifestiy impossible that he could have gone through the "megaron", that was filled with suitors. Eunalos and Philoitios go there 1mmediately after (176), and seize Melanthios. They, too, must have passud through the "laure".

We know only of this one "laure"; it is possible that there was another, on the opposite side of the nouse, situated in a symmetrical position. This "laure" did nos have an "orsothyre" opening into it, but was connected with. the back of the house in the same manner.

173. De Aedibus Homericis. p.49. $174.0 d . X X I 1.143$. 175. Od. XXII. 110. 176. Od. XXII. 279 . 

The Position of Odysseus puring the right.

In reference to the position of Odysseus during his fight with the suitors, Mr. Andrew Lang (177) says that it 1s very clear that he stood at the rear of the "megaron" when engaged in fighting. But before we take up his theory, it wil be necessary to examine in detail the description of the fight.

Odysseus is brought into the "megaron" by Telewachos, and seated near the stone threshold, presulnably fhat of the front door (178). The bow is then brought out, and the axes erected by Telemachos, and the suitors strive in vain to string the bow. Odysseus, however, strings the bow and shoots the arrow through the axes. He then jupps to the a great threshold and begins the fighting (179). Here he re mains during the fight. Telernachos, however, goes to the storeroom for arms, and the two servants, Eumaios, and Philoitios, also go there, to catch Helanthios (180). These constitute the main points.

Mr. Lang says that the stone threshold that is wentioned is a high, raised platform, faced with stone, placed at the back of the "megaron", at the entrance to the women's apartments. He assunes this to be the sane threshold that Penelope is said to cross, when she enters the "megaron", coming from her own room (181). Here Odysseus was placed by Telemachos on purpose, and the former directs Eumaios to bring the bow to him there, and to tell Eurykleia, at the same time, to lock the "Inegaron" doors (182). Eumaios, then, would bring the bow to odysseus, as he sat near the door of the women's apartinents, and at the same time would tell Eurykle1a, to lock the doors. And he also says, that through this door Telemachos and the two servants went to the stpdefoom, while Odysseus remained on the threshold; Melanthios, then, went through a sort of olerestory, his explanation of the "roges".

But there are several very obvious faults in such a theory. It is not exactly natural that the sultors should wait In the "megaron", and be shot down, when behind them was an open door, leading into the "aule" and thence outside.

177. The Odyssey of Homer, Butcher and Lang. Note 18.

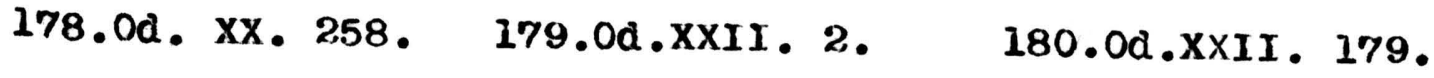
181.0d.XXII. 88. 182. Od.XXI. 234. 

on the contrary, we find that the suitors w1sh above everything to force Odysseus away from the door, in order that they may escape, or at the least arouse the town. First, Furymachos said that odysseus would stand on the threshole and k1ll them all; but they must try to force him from the doorway and get to the c1ty (183). Here they are surely not attempting to get out the back of the house, in order to get at the armor, but they aro striving to drive odysseus from the threshold and out of the way, so that they might escape. Agelaus asks Melanthios if it was possible for anyone to go out through the "orsothyre", and alarm the town (184). Thus wo see that their purpose was not to break through into the storeroom and get arms, but that their only thought was to escape.

But his position is given emen more clearly by a second speech of Agelaos. For when Athene, in the guise of Mentor, left them, Agelaos said that Mentor had left them and they were left alone at the "first doors" (185). Th1s expression can refer to no other doors than the front doors of the "megaron", and shows clearly that odysseus and his friends stood the front doorway.

It is very easy to account for the trips of Telenachos, Euraios and Philoitios, to the storeroom. They must have passed along the "laure", and gone to the rear part of the house, where the storeroom was located This is much more: natural than the theory of Mr. Lang, who assumed that the back door of the "megaron" was opened to them, while we know that express orders were given Eurykleia, to close this door, and not to open it if she heard any noise.

The Uses of the "Megaron".

As in the case of the "aule", we find that the uses of the "megaron" were varled. And this is very natural, for the "megaron" is the main room of the house, where the men of the family spent most of their time, and in some palaces we find that the women likewise use the "megaron" as a living-room.

183. Od. XXII. 77. 184.0d.XXII. 133. 185.0d.XXII. 250. 

In the house of Odysseus, where so many suitors were present, the "megaron" was of course crowded during the day. We see this from several passages. When Eumaios calne to the house, in company with Odysseus, he left his companion outside and went in to the haughty suitors (186). Leokritos, on one of the suitors, saie that not even if odysseus himself came home and tried to drive the suitors out of the "inegaron", would he able to accomplish his purpose (187). Athene advises Telenachos to plan how he may be able to thrust forth the suitors from the "megaron" (188). And Eurykleia bids the women hurry in their work in the "Inegaron", especially in cleaning it up, because the suitors w111 not stay away froll the "megaron" for a long time, but'will soon come in (189). All of these passages, especially the last, point to an habltual use of the "rilegaron", for a general assembly-room and living-room for the sultors.

The "megaron" of the house of Alkinoos was likewise used for a living-room both for the men and wowen of the famliy; furthermore, assemblies of the people of the tow were held there. When odysseus calne to the palace, he found Alkinoos and his wife Arete there, the latter weaving by the hearth $(190)$. When Nausicaa went to find her jother and father, she found them in the "megaron", her mother by the hearth, her father by the door (191). Both of these passages show that the "lnegaron"was used here in this palace, as a living-room for the whole family.

HEre also in the "liegaron", gather the chiefs of Phaeacia, probably on invitation from the king. When Odysseus first cane to the palace. of Alkinoos, he found the chiefs of the Phaeaclans there, as well as Alkinoos, and Arete (192). On the next day, at the assembly place of the "Bhaeacians", Alkinoos invited the chiefs to come to the house, in order to have a feast in honor of the stranger, Odysseus (193). Thus the "negaron" was also used for an asseinbly -place for the people of Phaeacia, and the king recolved his guests here.

We have additional proof in two passages, that they were assembled in the "megaron". For when they go away, it is

$$
\begin{array}{lll}
\text { 186.0d.XVII. 325. } & \text { 187.0d.II. 248. } & \text { 188.0d.I. } 261 . \\
\text { 189.0d.XX. 155. } & \text { 190.0d.VII. 141. } & \text { 191.0d.VI. 52. } \\
\text { 192.0d.VII. 136. } & \text { 193.0d.VIII. 41. }
\end{array}
$$



sa1d that Odysseus was left behind in the "luegaron"(194). Before this, Alkinoos had ordered the cup-bearer to pour wine for all the men throughout the "megaron"(195). This merely confirms the statements already made.

We have also reason to believe that any stranger, or guest, who might come to the palace, was immediately taken to the "megaron", and received there, by the fanily and the king nimself. When Telemachos and Peisistratos arrive at the house of Menalaos, they are brought into the house by the servants, and given a seat near lienelaos, wrio was: sitting in the "megaron" (196). Odysseus, too, when he comes to the house of Alkinoos, goes directiy into the "megaron", and is there received by Alkinoos and Arete (197).

In two other cases we find.the "Inegaron" used as a living-reom by both the men and the women of the family. For when Menelaos is talking to Telenachos, Helen comes into the "megaron" from her "thalamos", and a servant set a chair for her there (198). The servant also brings a basket filled with yarn, and a distaf'f (199). At the house of Odysseus, also, when Odyseeus is sitting alone in the "megaron", after the suitors had departed, Penelope comes in and has a chair placed by the fire, in order that she might converse with him (200). Both of these passages indicate that the "megaron" was the general living-room for the entire fanily. and was used as such.

The "megaron" was colmonly used as a dining-room, in addition to 1ts use as a living-room, both for the family, and for large feasts. In the house of Odysseus, Telemachos brings Theoklymenos into the "megaron", and dines with hili there alone, while Penelope sits opposite them (201). Telemachos and Peisistratos are also brought into the "megaron" of Menelaos, where there was already a feast going on, and seated near Menelaos in the "megaron" (202). Odysseus is given food by Alkinoos, when he colnes into the "megaron" as a suppliant (203). The chiefs of the Phaeacians were already in here, drinking wine, and pouring libations to Hermes (204).

All the above passages refer to nore quiet feasts, but we find that the "inegaron" of the house of odysseus was also

$$
\begin{aligned}
& \text { 194.Od.VII.230. 195.0d.VII. 280. 196.0d.IV.4389I. } \\
& 197.0 \text {.I. 130. 198.0d.IV.121. 199.0d.IV. } 133 . \\
& \text { 200.0d.XIX.53. 201. Od.XVII.93. 202.0d.IV. } 51 . \\
& \text { 203.0d.VII. I75. 204.0d.VII. } 237 .
\end{aligned}
$$



used for the banquets of the suitors. When Mentes caine to visit Odysseus, and was being entertained by Telemachos in the "megaron", the sultors came into the room, seated themselves in rows on chairs, and the servants placed tables near them w1th food (205). When Eumaios went into the "megaron", atter escorting Odysseus to the house, ho sat down by Telemachos, aliong the feasting suitors (206).

It is not necessary to mention all the passages which zefer to the banqueting of the suitors. These will surely show with sufficient clearness, that the "megaron" was used for that purpose, and was the dining-rooln of the men in the house of Odysseus, and the dining-room of the whole fanily in the other houses, where so many people were not usually assembled.

We find, also, that some of the food was prepared in the "megaron". In the house of Odysseus we hear of two instances where animals are killed in the "Inegaron" and their flesh prepared for eating. soon after the return of Telemachos from Pylos, when he was in the "luegaron", the sultors come from the "aule", where they had been engaged in gaines, into the house, and kill sheep, goats, swine and an heifer, in their preparations for the feast (2.07). On the next day they made the same preparations, and roasted the knowals,passing them around with wine(208). Then when they had roasted the upper flesh, and drawn it away, they served each of the persons in the hall with the meat (2,09). This shows us quite clearly the operation of preparing and cooking the food, and we know that it took place in the "megaron". The food was in all probability cooked at the heartn; this is, however, not at all certain.

$$
\begin{aligned}
& \text { 205.Od.I. 145. 206.0d.XVII.333. 207.0d.XVIII. } 180 . \\
& 208.0 d \cdot x x \cdot 247-255.209 .0 d \cdot x x \cdot 2 r y \cdot
\end{aligned}
$$



The Women's Apartments.

Passing through the back door of the"megaron", weecome. directly into the women's aprtments. Here are located the sitting-rooms of the women, some of their sleeping-rooms and work-rooms, and also the "thalanos", or sleeping-chamber of the mistress and master of the house, as well as the treasure-chamber, or storeroon.

There 18 also an upper story, to which access is had bymeans of a stairway. This stairway, or "hy peroion", as it is called, contains "thalanoi" of the same sott as those in the lower part of the nouse, and they are used for the same purpose, for sleeping and working in. The chamber of Penelope was located here, and here she oversaw the work of the servants. It is uncertain whether this upper story extended over the whole of the house; we are reasonably certain, however, that it did extend over the "negaron". For Odysseus, while sleeping in the "prodomos", heard Penelope weeping and mourning in the "thalamos" in the "hyperoion" (210). If the "hyperoion" was confined to that part of the house immediately above the lower women's apartments, it would have been manifestiy impossible for odysseus to have heard Penelppe from his position in the "prodomos", immediately before the front door.

\section{The Back Door of the "Megaron".}

At the back of the "megaron" is located the door which communicated with the rest of the palace, leading directly into the women's apartments, and so realiy belonging to them. The existence of a door here is shown by manf passages. Whon the sultors have all gone home, and Odysseus is left alone in the "megaron", it is said that the women-servants come out of the other part of the palace into the "megaron"(211). Whenever Penelppe wished to talk to the suitors, she always came downstairs to the "megaron", and stood by a pillar, probably entering this door (212). When Penelope gets the

210. Od.XX. 92.

211. Od.XIX. 60.

212. Od.XVI. 413.

See also, I. 334. \& XXI. 64. 

bow for the suitors to try, she gets it froin the storeroom, and brings it to the "megaron", where the suitors are assembled (213). In each of these cases, it is clear that it. is necessary to suppose that a door existed there, becaus the persons mentioned go directiy from the other part of the house into the "megaron".

We have also the threshold of the door mentioned, and people pass over and stand on the threshold; here, again, the door 1tself 18 not mentioned, but it is unnecessary. on the morning after odysseus' arrival at the palace, Telemachos questioned Furykleia, about her provisions for the beggar's coinfort. In order to speal to her, he went to the threshold and called her (214). It is certain here that he was on the threshold of the back door of the "rnegaron". When Medon heard the plots of the sultors, he went through the palace to tell Penelope about them, and she spoke to him, as he was crossing the threshold (2k5). A similar state ment occurs in another passage. Fumaios is sent by Penelope to bring the beggar in to her; as he is returning, bearing Odysiseus' refusal, he is addressed by Penelope, just as he was crossing the threshold (216). Both of these passages confirm the statements made, as to the existence of a door at the back.

Eut we also have the doors actually referred to, though of course they are not spoken of as the back entrance of the "megaron". We are, however, in no doubt as to what they refer then odysseus is preparing to kill the suitors, he tells Euma1os to order the woinen to keep the doors of the "megaron" closed, and not to come out if they heard any noise outside (217): Eumaios, later, tells Eurykleia that Telemachos has ordered her to close the door of the "megaron", and to allow none of the wolnen to go out (218). This unquestionably refers to the hack door of the "megaron"r which leads to the women's apartments just behind, and establishes the existence of the door beyond question.

The locatiob of the door is not given, nor is there anything to help in locating it. But the natural place would be near the middle of the wall, and this we may well accept as the correct theory.

$$
\begin{aligned}
& \text { 213.0d.XXI.58. 214.0d.XX. 128. 215.0d.IV. } 680 . \\
& \text { 216.0d.XVIII.575. 217.0d.XXI.236. 218.0d.XXI.381. }
\end{aligned}
$$



The door was made like any other door, in the same way as the front door, probably. The leaves are double, since Odysseus speaks of them as "doors", when he directs Eunaios to have them closed (219). The threshold of this door is of stone. This is shown from the passage that describes the meeting of Penelopeand Odysseus. For after the fight Penelope came from her chamber, crossed the stone threshold, and entered the "megaron" (220). This is the only reference made to any part of the door, but it establishes one fact that is valuable.

\section{"Thalamoi" virectly Behind the "Megaron".}

We have reason to believe that near the back door of the "megaron" was a sitting-room of the mistress of the house. At the house of Menelaos, Helen came out of her "thalamos" Into the "megaron", where Menelaos and Telemachos and Telemachos were sitting (221). As this occurs in the midale of the day, and since the servant brought along with her some wool fot spinning, presumably also out of the "thalamos", it is probable that the "thalamos" is a sitting-room. Penelope, also, when she carne into the "megaron" to talk with the beggar, Odysseus, is said to have come out of her "thalamos"(222). When Antinoos had just struck Odysseus, as the latter was begging of the suitors, Penelope heard of it, as she was sitting among her women-servants, in the "thadamos" (223). All these passages certainiy

refer to a sitting-room downstairs.

This same room is spoken of in other passages. When Medon, overheard the conspiracy of the suitors, he went in to tell Penelope about 1t, and she spoke to him as he crossed the threshold (2,24). He tells her what he has leatned, and departs, while she, overcome with grief, crouches on the threshold of the well-built chanber, and her women mourn around her (225). Here, again, this must refer to a "thalamos" in the first story.

When Telemachos returned from Pylos, he was first welcomed by all the servants, and then Penelope came out of her "thalamos, and greeted him (226). This "thalamos"was

$$
\begin{aligned}
& \text { 219.0d.XXI.236. 220.06.XXIII.88.291.0d.IV.22183. } \\
& \text { 222.0d.Od.XIX.53. 223.0d.XVII.506. 224.0d.IV.680. } \\
& \text { 225.0d.IV.718. 226.0d.XVII. } 36 .
\end{aligned}
$$



in all probability downstairs, because there is no statement of her descending the stair, as is usually the case when she does come from the "hyperoion". There is, they,a "thalamoa" on the ground floor, not far from the back door of the "megaron".

The Treasure-chamber, or Storeroom.

In every house in Homeric times, there was a treasurechamber, or storeroom, the "thalamos", the same room serving the purposes of both. Here are kept the precious treasures of the king, gold, silver, etc., and his arms and armor,. while the stores of the houschoid are also kept here, jars of wine, olive-0il, etc., and the cloth that has been woven in the house.

We have mention of the storerooin in four different palaces, and in each the contents are described more or less minutely. At the nouse of Odysseus, just before the journey of Telemachos to Pylos, he went into the storerooli to get supplies for the journey, and Eurykleia accompanied him. They went into the high-roofed "thalanos", where bronze and gold lay piled, and where there was clothing in chests, and olive 011. And casks of wine and 011 stood around the wall arranged in rows. The doors were locked and guarded by Eurykleia (226). Telemachos took twelve jars of wine, and twenty skins of barley (2.27). The contents of this "thalamos" are given rather more minutely than usual.

The treasure-chamber of the house of Menelaos is also described for us. Before the departure of Telenachos, Megapenthes, Menelaos, and Helen went into the "thalamos" to get presents for him. When they came to the place where the treasures were kept, Menelaos took a silver cup, Megapenthes carried a silver mixing-bowl, and Helen, standing near the chests where the beautiful garments were which she herself had made, carried out a beautiful robe (228). Here the treasures, only, are mentioned and we do not hear of the household stores, though it is probable that they were here.

$$
\begin{aligned}
& 226.0 d . I I .-337.346 . \quad 227.0 d . I I .353 . \\
& \text { 228. Od.XV • 99-105. }
\end{aligned}
$$



The "thalamos" of the palace of Alkinoos is also mentioned. The Phaeaclans all gave gifts to Odysseus, and Arete, to enable him to take them home with him, brings a chest out of the "thalamos", and places all the gifts in that, togetiler with a robe and a "chiton," which she also apparently brought out of the storeroom (229).

The contents of the storeroom at the palace of Priam are also enumerated, when he goes there to get presents for Achilles, as ransom for the body of Hektor. He went into the "thalamos" (230), and, after talking to his wife, opened the chests that stood there. Out of them he took twelve beautiful robes, twelve single mantles, twelve rugs, tweive beautiful cloaks, and also twelve "chitons". He took out besides, ten talents of gold, two glittering tripods, four basins and a very beautiful cup, all as ransom for the body of Hektor, and gifts for Achilies (231). This room evidentiy contained the treasures of Prlam. It nay have also contained the stores for the house, but they are not mentioned.

Ali these storerooms have been mentioned in a rather general inanner, and we know nothing about their location. But the storeroom in the house of odysseus has been alluded to in other passages, and described more carefully. When Odysseus and Telenachos were talking in the hut of the swineherd's, the former directs Telemachos to carry the weapons into the interior of the "thalamos", that is, into the interior of the storeroom (232). In order to do th1s without being seen, Telemachos orders Furykleia to lock up the women-servants in the rooms, so that.he might carry out his plan unobserved (233). This she does, and they carried the weapons in (234). During the fight with the suitors, Telemachos, at the bidding of Odysseus, went to the the "thalainos", and brought back spears, helmets, and shields(235). Melanthios, also, who had been in the "inegaron", went out to the "thalamos" to get armor (236). And Penelope, when she fetched the bow for the suitors, first went

$$
\begin{aligned}
& \text { 229.0d.VII. 439. 230.I1.XXIV. 192. 231.IIXXIV.228-235, } \\
& \text { 232.0d.XV1. 285. 233.0d.x1X. 17. 234.0d.x1X. } 30 \text {. } \\
& \text { 235.0d.XXII. 109. 236.0d.XXII. } 140 .
\end{aligned}
$$



upstairs to get the key to the door (237), and then went to the "thalamos", where the treasures of the ptince were stored, gold, silver, iron, and the bow (238).

When Telemachos went to the storeroou to get the arins, he went by the "laure", or passage, at the side of the nouse and thus was able to go and return, unnolested, to his position at the front door. Melanthios is said to have gone to the storeroom by means of the "roges" of the "megaron", and so was also able to.get to the "thalaiios" and return, without being hindered by odysseus and his ilen. We do not know what the "roges" of the "inegaron" were, but they must have been soine sort of passage at the back, affording access to the storerooin.

Penelope was in her own apartments, back of the "megaron", when she went for the bow, and so went straight to the storeroom, which is called "eschaton", or "at the extremity": This means that the "thalalios" was located at. the very back of the house, the part farthest away frorn the entrance.

The construction of parts of the "thalanos" is also given to us. The doorway was furnished with double doors, a threshold and door-posts, and the door could be locked. A p1llar"supported the roof inside, and there were cross-beams in the roof.

The existence of the varlous parts is shown in several passages. Odysseus sata that the sultors were getting arins, during the fight, and thought that the women were helping them, but Telemachos said that he had left the door of the storeroolu open (239). Eumaios spied Melanthios, and in company with Philoitios, went to the storeroon to seize him. They found him inside, and stood by the door-posts, on either side of the door (240). When Melanthios came out of the storeroom, and crossed the threshold with the armor in his hand, the two others seized him and carried him inside of the "thalamos" (241).

The different parts are mentioned more particularly in another passage. When Penelope brought the bow for the suitors, she went to the "thalainos", and went onto the threshold of oak, which a carpenter nad cut skilifully and made straight. (On the threshold he rad placed door-posts,

$$
\begin{aligned}
& \text { 237.0d.XXI.6. 238.0d.XXI.8. } 239.0 \mathrm{~d} . \mathrm{XXII} \cdot 155 . \\
& \text { 240.0d.XXII. 181. 241.0d.XXII. } 182 .
\end{aligned}
$$



and shining doors. She then immediately loosened the strap from the handle, and placed the key in, throwing back the bars, The goors groaned when opened by the key (242). The key is said to have been of bronze, with a handle of ivory. This describes quite fully the doorway and the operation of unlocking.

There is also a pillar in the "thalanos". For Odysseus Ordered Eunaios.and Philoitios to go to the storeroom and seize Melanthios and cast him into the storerooli. Then, having bound him, they were to haul him up by the lofty pillar, and fasten him against the roof-beains, so that he might suffer exceedingly (243). These commands they carried out, and having closed the doors, went back to Odusseus, at the front door of the "megaron" (244). The roof-beains referred to are probably the rafters at the top, running from the pillar.

\section{The "Thalamos" of Odysseus.}

Thw chamber of Odysseus is pleced in the rear part of the house, in the back part of the women's apartinents. It was built by odysseus himself, and was constructed around an olive tree, that grew inside of the wall, evidently when he was just bulding the house.

A description of the "thalamos" 18 given by Odysseus, to prove his identity to Benelope, who does not believe that the beggar is Odysseus. He says, "An olive tree grew inside the wall, with a trunk as large as a pillar; around this he built the "Whalamos" with closely fitting stones, and robfed it well above, and placed closely fitting doors upon it. Then he trimmed of $f$ the olive tree, waking it into $a$ bed-post, and beginning with trat, he completed the whole bed (245).

The "thalamos" was peobably the first part of the house built by odysseus. It had doors similar to those of any other "thalamos", and they could be closed so that no one could get in, for Penelope says that thots bed had never

242. Od. XXI. 342-350.

244. Od. XXII. 202 .
243. Od. XXII. 176 .

245. Od. XXIII. 190-200. 

been seen by anyone, except Odysseus, herself, and one woman-servant (246). This passage shows also that this "thalamos" is entirely distinct from the one upstaits, bet cause we know that the servants were frequently in that "thalamos".

Buchholz (247) and Ptotodicus (248) both place the " "thalanos" at the back of the house, as an isolated room in the back-yard. This location they doubtless give for the "thalamos" of Odysseus, because the "thalamo1" of other $k$ ings are said to have been in the "mychos" of the house, and they call this badk-yard the "rnychos".

There is no reason to suppose that the bed-room of Odysseus and Penelope was in the back-yard of the palace, rather than in the body of the house. In the first place, if the "mychos" of the house were the back-yard, there is no statement in Hoiner that this bedroom was in the "inychos". In the second piace, we will endeavor to show that the "mychos" was not a back-yard.

\section{The "luychos" of the House.}

The word, "Inychos", is used with the significance of the interior part of anything, usualiy the part farthest from the entrance. Its use is not confined to any particular thing. It is applied alike to cave, room, hut, or house, with the saine significance in each case. When Doysseus was held prisoner in the cave of the cyclops, it is said that they ran in terror into the "mychos" of' the cave (249). When Telenachos removed the weapons from the "megaron", he was told by Odysseus to place them in the "mychos" of the lofty "thalainos". or storerooin (250). Melanthios was tound by Eumaios and Philoitios searching for weapons in the "mychos" of the storeroom (251). After the death of Patroklos, when phontus was fighting with Menelaos, he told Menelaos, that he would have to pay for the death of his brotner, whose w1fe was left a widow in the "Iny chos" of the "thalamos" (252) Achilles is also sald to have slept in the "mychos" of his

246.0d.XXII. 227. 247. Howerische Realien. Vol. VII. Sect.14. 248. De Aedibus Homericis. p.60. 249.0d.IX. 236 . 250.Od.XVI. 285. 251.0a.XXII. 180. 252.II.XVII. 36 . 

hut (253). This gives us the use of the verd "inychos", in the meaning of interior, 1.e., the part farthest back from the entrance.

Buchiolz (254) and Protodicus(255) have another theory about the "Inychos" of the house. They unite in caliing it a second court, a yard inside the surrounding wall, but at the back of the house, and taking the place for the back part of the house, which the "aule" takes for the front.

We find it applied in the same way to the house as it was to the cave, room, etc. Nestor and his wife slept in the "mychos" of his house (256), and, likewise, Menelaos and Helen had their "thalamos" In the "mychos" of their house (257). We find also that Arete and Alkinoos had their "thalamos" in the "inychos" of the house (258). These three passages show clearly that the "thalamos" of the master of the house wes situated as a rule in the "mychos" of the house. And since we have proved that in the case of a cave, a room or a nut, the word "inychos" is used in the sense of the "Interior", we cannot believe that the meaning of the word, would, in the case of the house, be so changed as to mean a yard at the back of the house, having little or no connection with the house itself.

This is even more clearly proved, nowever, by an occurmence in the palace of Priam. For Androinache, ignorant of the death of Hektor, was sitting in the "Inychos" of the lofty house and weaving (259), and when she reard the news, she rushed through the "megaron", like one mad (260). It is certainly absurd to think that Androinache would sit and we weave out in the bablyard, where also, according to the theory of Buchholz andeProtodicus, the stables of the horses were located, and this is what we would have to infer, if *e followed their theory. Apart froin the fact that she must have been in the women's lower apartments when she was weaving, it is also said that she hastened out through the "megaron", and this shows that she must have been directly behind it.

\footnotetext{
253.I1.IX.663. 254.Hornerische Real1en. Vol. VII.Sect.74.

2.55. De Aedibus Homeric1s.'p.bl • 256. Od.tII. 408.

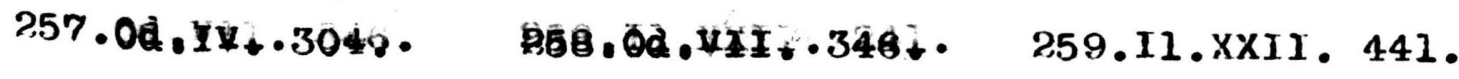

280. II.XXII. 460 .
} 

The "mychos", therefore, includes all the space back of the "megaron" which forms the women's apartments. The "thalamoi" of the women are in it, the "thalanos" of the master of the house, and also the storeroom.

\section{The Bathroolas.}

The existence of bathrooms in the Homeric house is clearly shown from the number of times that they are referred to, but their location is not given in any passage, except in those fndicating in a vague manner that they.are on the ground floor and hot far froli the "megaron".

We have bath-tubs mentioned in several instances. Menalaos received two silver bath-tubs from an Egyptian $k$ ing, when he was on his travels (261). When Theoklymenos and Telemachos reach the house of Odysseus, they go to the polished baths, and bathe (262). Telemachos and Pisistratos, upon their arrival at the palace of Menelaos, go to the polished baths, and bathe (263).

When we come to consider the location of the baths we neet with considerable difficulty. Perrot and Chipiez (264) say that the bathrooms are outside of the house, opening upon the "laure"to the right of the "megaron", and are connected by means of this "laure" with the woluen's apartments, so that attendants could be at hand without being obliged to come through the "megaron" and around. But this arrangement places the baths a littie too far from the "megaron"thyseen to have been placed nere so tnat it would be convenient for the women. But, as a matter of fact, the women could go to any part of the palace, and this is no argument for that location.

We know that the baths were downstairs, because Telenachos, talking to Penelope, bids her bathe and take fresh clothing, and then go upstairs and pray to the gods (264). This shows at least that they were not in the upper story. We can see froln other passages also that the baths were not far from the "megaron". When Telenachos has brought Theoklymenos into the house, they first go to the baths, and then take seats in the "megaron", in order to eat (262). And when Menelaos receives Telernachos and his companion in

261.Od.IV. 128. 262.0d.XVII. 87. 263.0d.IV. 48.

264. Od.XVII. 48 

his palace, they, also, when they have bathed, take seats in the "megaron", near Menelaos(263). In both of these cases it is very clear that the bathrooins could not have been at any very great distance from the "megaron", or the passing to and from the baths would be mentioned. We have no furhter information about the location of the baths. There are, it is true, other passages where it is mentioned, but they add nothing to what we have already learned.

The bathroom at the palace of Tiryns was: situated not very far from the "megaron", on a passage which lead from the antechamber of the "megaron" to the rest of the palace. We may have possibly havesolve sort of arrangement like that here but $1 \mathrm{t}$ is more likely that the bathrooms were in the women's apartments, not far froil the back door of the

"megaron".

\section{The "KIImax", or Stairway.}

Not far from the back door of the "megaron", ptobably rather close to 1t, was the stalrway whlch leads frolin the upper part of the house to the wolnen's lowereroous. We see this froln passages which merely say that some one went up or down, to and from the "hyperoion", or upper story "These are all in connection with Penelope. She nas been talking with the suitors at the doopeoflthe "inegaron", and, at the bidding of Telemachos, ascends to her upper chamber, to sleep, and to nourn for Odysseus (265). A second time, after the return of Telenachos from Pylos, she entered the "megaron" to talk to the sultors, and when she had recelved their gifts, she ascended to the upper chamber (266). We find the same statenent made just before the slaughter of the suitors, when Penelope had borne the bow to the "megaron" (2.67). She is also said to have descended from the upper story, when she wished to speak to the suitors, shortly after the return of Telemachos froin Pylos (268).

But we know most surely of the existence of a stairway from the fact that $1 \mathrm{t}$ is mentioned in several passages. Penelope, hearing the song of Phemios upstairs, comes down

265.0d.I.362. 266.0d. XVIII.302. 267.0d.XXI. 356 . 268 . . Od.XVIII. 206. 

the lofty stalrway and asks nim to stop singing that particular song(269). She is also said to have ascended the stalrway, in order to go th the "thalamos" and get the key of the storeroom (270). All these passages have reference to the house of odysseus, and clearly prove the existence of a stairway there.

There, 1\$ in addition, a stairway lientioned in the palace of circe. Elpenor had cllimed up to the roof of the house to sleep, and, since he had had too luuch wine, when awakened by his colrrades, leaping to his feet in a hurry, did not descend by the lofty stairway, but fell directly from the roof (271). Th1s stalrway must have differed somewhat from the others we nave inentioned.

The stairway of the house of Odysseus led only from the flrst floor to the second floor. But the stairway of the palace of Circe extended apparently from the ground, clear to the roof, sotthat one inight ascend from the ground to the to of the roof. Eut this may have been in the nature of a ladder.

It is not so easy to locate the stairway, as it is to prove 1ts existence. We have every reason to believe, however, that its foot was near the back door of the "megaron". For whenever Penelope descends the stairway froli above, she appears 1mmediately in the "wegaron", before the sultors. The stalrway is called "lofty", in every case, but further than this, we know nothing about its form or structure.

\section{The "Hyperoion", or Upper story.}

Tho stalrway leads from the lower women's apartuents to the upper story, or "hyproion". In the "hyperion" was located a room for IIving and working in. It may also have been the room in which slept. We see that this was probably a living-room from the fact that the gifts, which were presented to her by the suitors, were taken upstairs with her by the servants (272). It 1s also sald that when Phemios was singing in the "megaron", Penelope heard him as she was in her upper chanber (273). This cortainiy refers to a living-room, since the incident took place in the middle of the day.

269. Od.I. 330. 270.0d.XXI.5. 271. Od.X. 558. 272. Od.XVIII. 302. 273..0d.I. 330. 

In the "hyperoion" was also located the sleeping -room, or "thalarios", of Peneloge, as is made clear from tho following passages. She, talking to Odysseus in the "negaron", says she w11l go upstairs and go to bed, to pray and mourn for Odysseus (274). We have the same statement repeated, in her conversation with Telemachos, soom after his return from Pylos (275), and the same idea is found in other passages where she leaves the presenco of Telemachos, with the same remark and purpose(276). After the slaughter of the suitors, Eurykleia offers to go upstairs and tell Penelope, who is upstairs asleep; about the battle, and reveal the identity of Odysseus; but sie does not carry out her plan, because odysseus prevents her (277). While Teleliachos was preparing to leave for Pylos, he made his preparations without his mother's knowledge. He sald to Eurykleia, that he would take the food and other things she had prepared, at evening, when Penelope went upstairs to retire (278).

The fact that a room of the "hyperoion" was used as a workroom, is shown by the following passages. When Penelope came to the "megaron", to prevent Phemlos from continuing with his song, she was told by Telemachos to go into the other, part of the house, and take care of ner own tasks, such as weaving and spinning, and to direct the work of the servants (279). Penelope obeyed him, and went directly upstairs. (280). This same statement is made later. Penelope had given the bow to the suitors to try, and all have failed. When Odysseus took the bow, Telemachos bade Penelope leave the room and attend to her tasks(281), and again she goes upsta1rs(282). Both of these passages point to the existence of some room in the upper story, where work was carried on by Penelope herself, and where she could superintend the work of the servants. There is another instance of this same thing. Theoklymenos asked Telenachos who in Ithaca would recelve him, and Telenachos said he would send him to $h 1 s$ own house, except for the fact that he nimself would be away, and his mother did not come into the sight of the suitors, but wove the web apart from them, in her upper roon (283). It is barely possible that the rooms of the womenservants were located in the uppersstory; it is at any rate probable that they were at some distance from the room of Penelope. For when Eurykle1a went to the rooms of the woinen,

$$
\begin{aligned}
& 274 . X I X .594 . \quad 275.0 d . X V I I \cdot 60 . \quad 276.0 d . X I X .602 . \\
& 277.0 d . X X I I .427 .278 .0 d . I .358 . \quad 279.0 d .1 .356 . \\
& \text { 280.0d.I.362. 281.0d.XXI.350. 282.0d.XXI.356. } \\
& 283.0 d \cdot x v \cdot 517 .
\end{aligned}
$$



in order to call them for Penelope, she went through the house after them. While she was gone, Athene caused Penelope to go to sleep, and the women, coming into the room through the palace, wwakened her (284). It is not said here that Eurynome went downstairs, nor that the other servants came up, so it is probable that the rooms were on the upper floor. And since Penelope had time to fall asleep, while Furynome was going and returning, we may judge that the room rooms were at some distance from her "thalainos".

of the form and arrangement of these rooms upstairs, we know very little. The roon of Penelope was probably over the "megaron", because Odysseus, sleeping in the "prodoinos", before the "megaron" door, heard Penelope weeping in her "thalanos" (285). Had her chamber been at the back, it is not probable that odysseus could have overheard her. But the arrangement of the other roons is not clear. 



\section{Other Ancient Palaces.}

In order to get a clearer 1dea of the Homeric house as a whole, It will be of advantage to compare it' briefly with some of the palaces of tge Mycenean age, that is, Tityns and Mycenae, and also with thosenoro recently excavated, namely, Phaistos and Knossos, in Crete. inese two seem to belong to a somewhat older period.

The Palace at Tiryns.

When we examine the ground-plan of the palace at Tiryns, we see immediately that it is planned upon quite a different scale from the Homeric house, and upon one which is much more elaborate. In entering the palace, it is necessary to pass through a gate, and then through two "ptothyra", before one gets to the larger coutt. This is paved, has an ltar in it, and a colonnade around the sides. Through it we come to the large "megaron", the so-calied "riegaron" of the men.

The entrance to this "megaron" is rather complicated, consisting of a vestibule and an antechamber. The "Inegaron" itself has four supporting coluuns, with the nearth in the centre, and has a paved floor. There is no other door. Access to the rest of the palace.is had by means of a door in the wall of the antechamber. The passage leading from : this brings one directiy to the bathroom, a stonezined pit, and then through a rather complicated system of corridors to the second "aule" and "megaron", the so-called women's apartments. This set of rooms is planned on the same principle as the other, but it is not so large in any way. The "megaron", though sinaller than the other, has four columns arranged in the salne manner, and in the centre of that space 18 a rectangular place that was very probably the hearth. The entrance to the second "megaron" is also less complex then that to the other, consisting of only a rather deep vestibule. Around this "megaron" and between it and the larger one id a rather complex system of suall rooms and corridors.

When we compare this place with our idea of the Honeric house, we notice several marked peculiarities, both in similarities and oissimilarities. 

The contour of the wall of this palace is very irregular and the wall itself is arranged with regard to its defensive qualities. The wall of the Homerlc house was rectangular, and not especially designed for defense. The entrance, also, differs from that of the Homeric House, in that it is more complicatod and more circultous. The entrance of the Homeric house is located in the exact middle of the front wall of the "aule", and consists of a single "prothyron". The entrance of the palace of Tiryns is at the side, and it is necessary to traverse a long passage between two walls and enter a gate, before one reaches the first "prothyron". After passing through this entrance, we come to another "prothyron", placed at right angles to the first. Then through this smaller "prothyron" we come to the large "aule".

This "aule" is different frow that of the Homeric house in many respects. It is probably much smaller; and it has a paved floor. The altar,likewise, is placed on the south side, while it is very probable that in the Homeric house the altar was in the midcile.

The "prodolnos" of the Holleric house was, at the most, only a shallow vestibule, and the door of the "megaron" opened directiy into 1t. The entrance of this "megaron" is composed of, first, a vestibule, with two columns between antae, and, second, an antechamber, with three doors leading inbo. it from the vestibule. This antechamber, in turn, opened upon the "megaron", by means of one large door.

The "megaron" is also paved, thus affording another contrast to the Homer1c house, the "megaron" of which had a floor that was composed of natural earth. It has only this one entrance, whereas the Homeric house has a door at the back of the "megaron", by which one can pass to the other part of the palace.

When we leave the "megaron", and coue to the other part of the palace, we find no likeness at all to the arrangement of the Homeric house. There are in the Homeric house a few rooms behind the "megaron", and they are directly connected with 1t. Here there is a complex system of corridors and small rooms on the passage which leads froin the door in the antechamber, and on the other side of the large "negaron", there is the smaller "megaron", with its "aule" and entrance. 

In the Homeric house we find no such second court and "megaron". In fact, this forms the greatest contrast to the Homeric house, namely, that there are so many rooms outside of the two "megara" that have so little connection with them.

We do find some marked likenesses to the Homeric house. In the general arrangeinent of the "megaron" and "aule" we see a decided similarity. Probably, also, the general form of the "prothyra" was like that of' the Tiryns palace, that 1s, with a double-porticoed entrance. The "aule" has the "aithousa", or colonnade, on three sides, and the front of the palace forms the fourth. In the Homeric palace we found that there was an "aithousa" on all four sides, but that is only a slight difference.

The megaron" shows solue likenesses, in that there is a hearth in 1t, which is located in the centre of the room. The "megaron" has supporting pillars, aswo, but as we do not know the arrangement of the pillars in the Homeric "negaron" we cannot say that there'was the same arrangement as there. is here, namely, four colums arranged in a square. Here the points of resemblanee vease, sinceour knowledge of the arrangement of the Homeric house ends with the "megaron". We know of the existence of rooms beyond the "megaron", but we do not know how they. were arranged. 

The Palace of Mycenae.

The remains of the palace of Mycenae are somewhat nore scattered and fragmentary than those of Tiryns, and therefore no such elaborate arrangement of the rooms has been discovered. But even then, the palace is planned upon a much more elaborate scale than the Homer 1c house

The entrance to this palace is nearly as circuitous as that to the palace of Tiryns, since one must turn sharply in entering, ascend some steps, and then turn again. The entrance to the "aule" 1tself has been 1ost, and the side opposite the entrance has also disappeared. To the left of the entrance of the "aule" inside, is a mass of buildings adjoining the "aule" wall.

There is a "megaron" adjoining this "aule", just as in $t$ the case of the Tiryns palace, and it has the same double entrance, with a vestibule and an antechamber, but only one door leads from the vestibule into the antechamber, and one from the antechamber into the "megaron". This "megaron" has a paved floor, much like that in the palace of Tiryns, with a hearth in the middle, and four supporting colums. Unfortunately, more than half of the folindations have been destroyed; but there was no door leading out of the "megaron", except the front door.

At the side of the palace mere apartments of the same sort as we found at Tiryns, with rooms interiningled with corridors, and there must have been some passage leading to'the rooms from the "aule", since there is none from the "aule" and none frol the antechamber. There were probabiy many moe of theseb but the foundations have been destroyed.

In the case of the palace of Mycenae, as in the case of the palace at Tiryns, we find many things which differ from our conception of the Homer1c house. The irregular contour of the wall, and the circuitous entrance both differ from the rectangular enclosure of the Homeric house, with its $s$ simple entrance, merely a "ptothyron" in the front wail.

When we take the "aule" under consideration, we find that it must have presented a wholly different aspect from that presented by the "aule" of the Homeric house. It was paved, had no "althousa" and, as far as we ean tell, had no altar,iolther in the centre, or any where else. The "aulek of the palace of Tiryns reseinbled that of the Honer 1c house more than this. 

When we turn to enter the "megaron", which can be entered directiy from the "aule", we notice another difference, in the construction of the entrance. As opposed to the simple "prodomos" of the Hoineric house, we have here the same double entrance that we noticed at Tiryns, consisting. of a vestibule, and an antechamber. There is this one differ. ence, howevere, in that the vestibule here has only one door leading into the antechamber, while that at the palace of Tiryns, had three doors. Otherwise the construction of the two. is the saine.

The "liegaron" of the Mycenae palace also differs from that of the Homeric house, in that it has a paved floor, and has no second outlet to the otrer part of the palace. There may have been otner differencs, but, as we have said, the greater part of the "megaron" has been destroyed.

With regard to the rooms outdide of the "megaron", the Homeric house also differs frou the palace of Mycenae. There were certainly a few roous behind the "megaron" in the Homeric iouse, but their arrangenent must have been rather simple, and they were connected directly with the "megaron", and were directiy behind it. But the outside rooins of the palace of Hycenae are scattered all around the outside of the "aule" and the "megaron", and there seens to have been no regular arrangenent, and no direct connection with the "megaron". The whole systela of roolns was probably more elaborate than that at the Homeric house.

There are some likenesses to the Homeric house here, but fewer than in the case of the palace of Tiryns. In general, the "inegaron", with the "aule" before it, is an arrangement very like that of the Homeric house, but in its detalis the house is very different. The "megaron", only, presents some points of similarity. In the "megaron" are four supporting coluuns, and a hearth is placed at the centre of the space formed by them. 

The Palace at Knossos.

When we take into consideration the lately excavated palace at Knossos, we are dealing with a vastly more elaborate palace tran either that at Tiryns, or that at Mycenae, and therefore with one which has few Iikenesses to the Homeric house. Fortunately, the foundations have been very preserved, so it 18 comparatively easy to see how the lower story, at least, of the great palace was arranged.

The general outine of the palace is square, with an oblong court in the middie. There are entrances on all four sides. On the west side was a paved court, in which.were altar-bases and on this side was probably the state entrance which opened into the court. This entrance is on the southern send of the western side, and is the only door in that side, the $r$ st being merely a blank wall. A corridor leads from the west side and its portico, to tre southern propylaeum, and this entrance leads to a small court, which also had an altar-base. Beyond this court, to the north, is a complicated mass of rooins, serving probably as offices, or small storeroons.

To the west of this block of rooms, on the western side of the bullaing, is the long corridor, with its series of magazines. The corridor runs north and south, for nearly the whole length of the palace, and the magazines are long narrow storeroons, which formerly held, for the most part, great stone jars. These magazines open onto the passage for nearly its entire length, occupying all the west side, and a small part of the east.

On the north side of the bullding is another entrance, which probably led to the city. Along the road leading to this entrance, were erected forts and walls. On this sicie of the palace,also, were bulldings, and rooins and corridors are mixed up just as at the southern end, near the central block of rooms. But there is one thing that is noticeable here, and that is that the rooms for the most part open directiy into one another and corridors are rather infrequent, but where they do occur, they are quite long. There is a bathroom on the north side, not far west of the northern entrance. On the northeastern corner is located another block of rooms, . and some nore magazines. There is also a ratier large hali situated here. 

The eastern side of the palace has not been wholly excavated as yet, but it is very probable that there was an entrance on this sdde also. But there are stili manj rooms on the East side, and this seems to have been an impottant wing. Here there are several large "megara", with antechambers, and small courts in front of them. These halls and the corridors which happen to be near them, are as a rule named from some peculiarity of structure or of decoration. Such are the Hall of the Double-axes, so-called, because the walls are carved with double axes, the corridor of the Bays, the corridor of the Draught-board and the Hall of Columns. Both of the halls have sliall open courts before them, and seem to be apartinents, separate froil each other. Both off the them are paved, and indeed we f'ind paving all through the falace, in rooms and courts alike.

The part south of these has only lately been excavated. Here, too, is a large block of rooms, seemingly used for domestic purposes, and arranged much like the rooms we have already mentioned. In the midst of them is located a larger room, the Queen's "Megaron, which also has an open court in front of it. Inis a little smaller than elther of the two "megara" mentioned above, but it is formed on the same principle.

In the centre of the palace, enciosed on all four sides by the buildings, is the great central court. Originally it was paved, but now, only a very little of the original pavIng remains, enough, however, to proveits former existence. From this court it is possible to go directiy to any of the main entrances, and it is connected with the small court that lies in front of the southern entrance. West of this court lies the complicated mass of buildings mentioned above. In the midst of these is the so-called throne-room. This is entered by meass of a raised antechamber, three or four steps above the level of the floor of the coutt. This room has a "thronos", or large chair, in it, but it has never been definitely proved that this was actually the throne-room.

It is nearly certain that there was a second and perhaps a third story.to this paiace, but there are few remains of stalrways that would lead above. But probably there was a vory large "megaron" situated near the southern propylaeun, where people came directly into the palace. Tnis "megaron" 

1s, then, above the small court with an altar-base, which we mentioned above. On aecount of the extra thick walls in one part of the east wing, it is also supposed that there $w$ was a great "megaron" above this place also. In the rast $w$. wing are several stairways, the one above the other, and it is quite probable that these stairways are continued above and formed a lileans of access to the second story.

A thing which we notice especially in takinga general survey of the whole palace, is that the walls as a rule seem to gave been placed at right angles to each other, and that it is possible to draw a line clear across the ground-plan, which will include some of the more important walls. This is possible in many cases, either from north to south, or from east to west. The whole palace seens to have been bullt on these lines, with the main walls parallel and at right angles to each other.

When we compare this palace with the Howeric house as we have concelved it, we do not find many points of similarity, principally because this palace was ever so much more elaborate, and covered so much more ground. The palace had no wall around it as the palaces of Tiryns and Myconae had, especially adapted for defense, and probably not so large a wall as the Homeric house, except on.1ts north side, where the road led toward the c1ty. There are several courts here, any one of them as large as the "aule" of the Homeric house, but they do not seem to have served as "aulal" for any special "megara", and are merely courtyards in the palace.

In the Homeric house there was a single rool that served as a storeroom, and here were placed stores and treasures aliko. But in this palace we find one whole side giveh,up to the magazines, which were the storeroons for probably only the household stores. This thing alone shows the difference in size of the two palaces. In the complicated grolfps of rooms we find another great contrast to the Homeric house. These rooms apparently opened directiy into one another and had few connecting corridors. The Homeric house has no arrangement of the rooms which could be compared with this. In some respects however it does resemble the Homeric house. For we find "megara", on the eastern side of the palace, which have little pprticoes and sinall courts in front of them, and they are arranged somewhat like the "megaron" of the Homeric house. And it is probable that the propylaea 



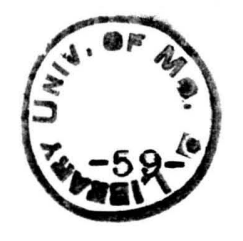

were constructed in much the same fashion as those of the Honeric house. The Homeric house was rectangular in shape and every thing was arranged in right angles; this we find here, in the palace of.Knossos, and in this respect it is like the Homeric house. But in generad we say that the palace at Knossos has very little in common with the Homeric house and was the product of a different civilisation.

\section{The Palace at Pha1stos.}

The palace of Phaistos is a palace of the sane age ass that of Knossos, and is constructed on much the mame plan. It is rectangular in 1 ts general shape, has a large central court and many blocks of rooms. It has never been so fully excavated as the palace at Knossos, probably never having been so extensive in the beginning, and it is not possible to give such a full description. But this full description 1s hardly necessary, since what is true of Knossos, 18 also true of Phaistos, and hardly needs to be repeated.

The entrances to this palace have never been fully excavated, but it is probable that there was one on each side, just as is the case at Knossos. On the south side, the part least excavated, there is a confused mass of rooin, which are joined one to'the other, with few corridors. This.1s on the west side of the central court. Farther north, still on the west side, is a corridor with magasgess arranged on both sides of it, much like the magazines at Knossos, only solnewhat shorter and less numerous. Still farther north, and somewhat farther to the west, is a broad flight of steps, which leads through a sort of vestibule to the great hall of Phaistos. This stairway faces west, and the west court is placed at the foot of the steps.

East of the hall, north of the central court, is another block of rooms, also arranged in a rather complicated manner with few corridors. To the east of this block of rooins, and more to the east of the central court, the excavations have not been so successful, and not much has been discovered. We see, then, tnat the palace of Phaistos is very like the palace of Knossos in 1 ts general forms, and we do not need to take up in great detail the special differences 

between it and the Howeric house. But the arrangement of the great "megaron" of the palace must be considered, since it is very.different froin that of the Homeric house. In the latter there was a simple entrance frow the "aule" into the "megaron". Herewrien one passes froll the court onto the "megaron", it is necessary to first ascend a flight of steps and then pass through a vestibule with two doors, which is very narrow, and then pass through another entrance into the "megaron", which has a row of three coluuns extending across the front. This arrangenent is wholly different from that in the Homeric house.

The palaces which have been considered form, therefore, a sort of descending series, as one might say. First comes Knossos, very elaborate and very extensive, then Phaistos, not far different frorn Knossos in its arrangements. Tiryns is the next in order, not so elaborate as Phaistos, but not far behind it. Mycenae is somewhat less extensive than Tiryns, and is in a somewint nore ruined condition. Last of all in this series is the Homeric house, which is plainiy a far less elaborate building than any of the above palaces. The Cretan palaces are trie oldest, the Mycenean are next in age, while the Holnerlc house is probably the lates of all. This period, then, in which the Howeric house was constructed, must have been one of decline, at least in architecture.

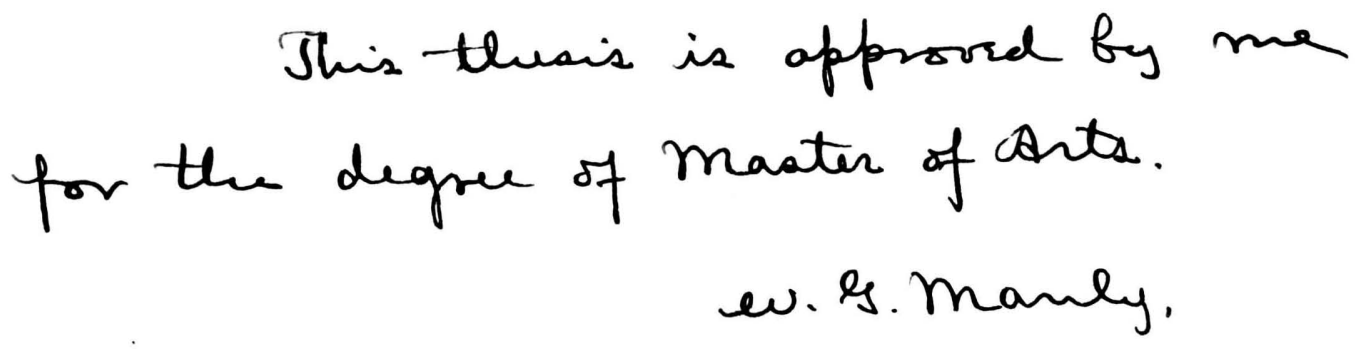

may 1 at, 1904 . 





\section{$378.7 \mathrm{M} 7$ \\ XW44}

$010-100965626$
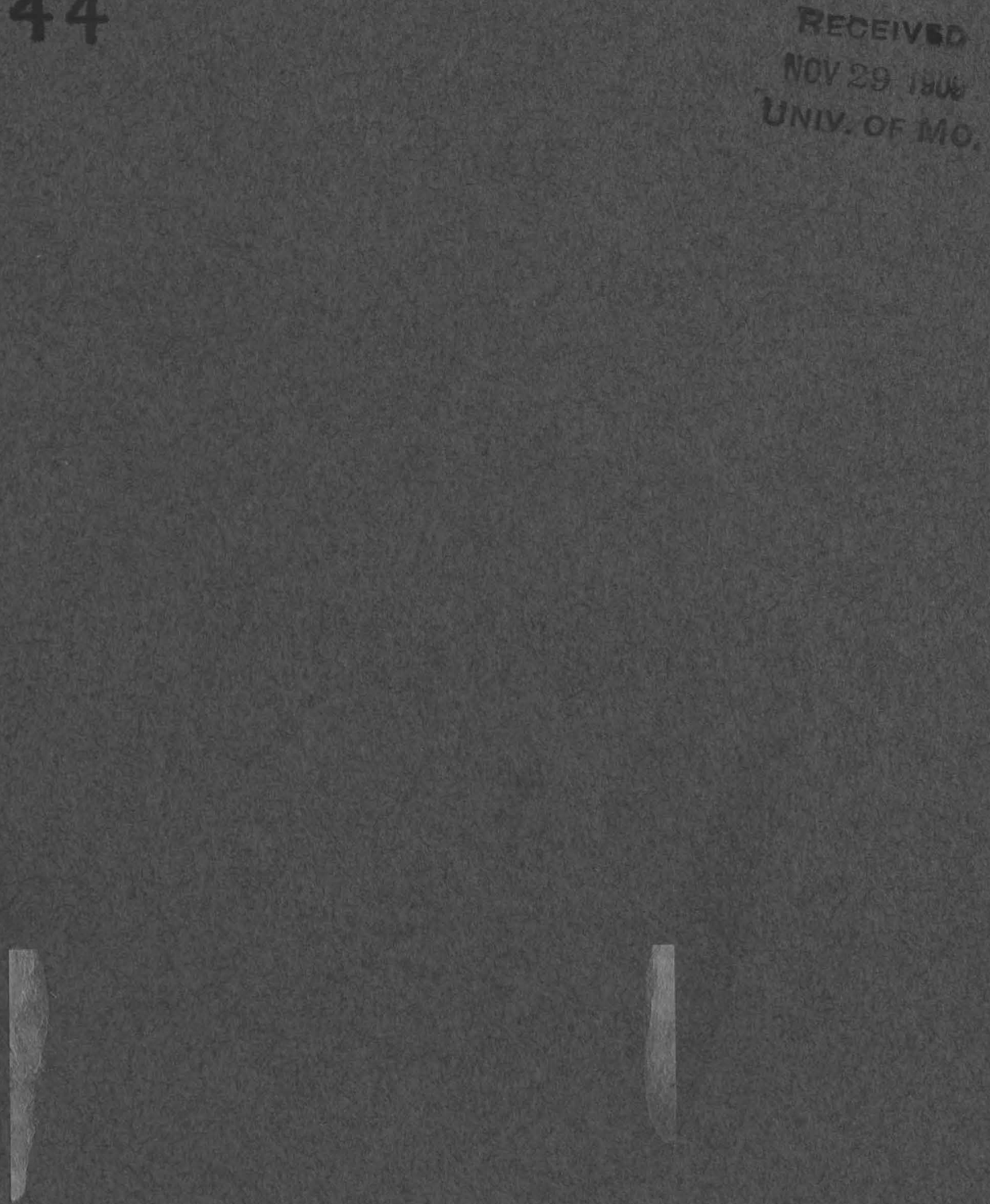

This thesis is never fol leave this room. Neither is it to be checked out overmigit. 
